\title{
Folkloor ja eluloolisus Venemaa eestlaste mälestustes ${ }^{1}$
}

\author{
Anu Korb \\ Eesti Kirjandusmuuseumi Eesti Rahvaluule Arhiivi vanemuurija \\ anu.korb@folklore.ee
}

Teesid: Käesolevas artiklis analüüsin, kuivõrd kasutavad Venemaa eesti kogukondades sündinud ja kasvanud eestlased oma elulooliste mälestuste edasiandmisel folkloorset ainest. Allikaks on eestlastelt, kes nõukogude võimu päevil Eestisse elama asusid, 21. sajandi esimesel kümnendil kogutud mälestused, mis on saadud vastustena üleskutsele talletada oma küla- ja perelugu. Folkloori puhul on läbi aegade rõhutatud kollektiivsust, ent arusaam kollektiivsusest on ajas muutunud. Üksikmälestuste osatähtsus arhiivides ja uurimustes on alates 1980. aastaist kiiresti kasvanud ja see on kohati muutunud lausa esmaseks uurimisobjektiks.

Rahvaluules on tavaline, et konkreetsete isikute ja paikadega seostatakse rahvusvaheliselt levinud süžeid ja motiive. Folklorist lähtub küsitlemisel sageli rahvaluuleliikidest, kuid vastajad toovad esile enesekohasuse, põimivad vastustesse oma elukogemuse. Kuna inimeste elukogemuses on pärimuskeskkond loomuldasa olemas, lisandub rahvaluule kogumise käigus seegi teave.

Artiklis toon Venemaa eestlaste mälestustes esile mitte pelgalt rahvaluuleliike puudutava teabe, vaid ka selle eluloolise aspekti. Venemaa eestlaste eluloolisus on äärmiselt kollektiivne, folklooriga läbi põimunud, sest kogukond suhtles omavahel just sel viisil.

Märksõnad: elulugu, folkloor, kogukond, mälestused, Venemaa eestlased

\section{Sissejuhatuseks}

Käesolevas artiklis analüüsin Venemaa eesti kogukondades sündinud ja nõukogude võimu päevil Eestisse elama asunud eestlaste eluloolisi mälestusi, mis on kogutud 21. sajandi esimesel kümnendil vastustena üleskutsele oma lugu kirja panna.

Siin käsitletud lugude jutustajate esivanemad olid 19. sajandi viimasel kümnendil või 20. sajandi algul oma maa otsinguil välja rännanud või sattunud sinna veelgi varem muul moel, näiteks sõjapõgenikuna või tsaarivalitsuse 
perioodil väljasaadetuna. Lugude autorid olid sündinud-kasvanud Venemaa eesti kogukondades ja emamaale naasnud Eesti Vabariigi annekteerimise järel, ajavahemikul 1944-1976 ning oskasid vähemalt suhtlustasandil eesti keelt. Nende hulgas oli lapsena koos vanematega Eestisse tulnuid, paremate töö- ja eluvõimaluste otsingul täiskasvanuid ning mõnevõrra ka elatanud inimesi. Venemaal oli elatud külades, Eestis asus 67\% neist elama linnadesse (Kulu 1997: 189).

\section{Individuaalsus ja kollektiivsus folklooris ja mälestustes}

Paljude aastate jooksul on folkloori mõistetud minevikku kuuluva, anonüümse ja kollektiivse kunstilis-kirjandusliku pärimusena. Folkloorikandjana nähti eeskätt maarahvast. Rahvusriikide tekke perioodil rõhutati, et maarahva minevikuhõnguline kultuur esindab ajaloolisi väärtusi, mis on vajalikud rahvusliku identiteedi kujundamiseks. 20. sajandi viimasel veerandil on üha enam loobutud rahvaluule käsitlemisest minevikulise nähtusena, seda nähakse pidevalt areneva ja muutuvana, protsessina (vt nt Honko 1990). Ülo Valk toob folkloori ehk rahvaluule põhitunnustena esile selle tuginemise traditsioonile, ulatusliku varieeruvuse, võime võtta kindlakujulisi kunstilisi vorme, anonüümsuse ning pärimusrühma maailmavaate väljendamise ja kujundamise (Valk 2005: 11). Tiiu Jaago esitab 1999. aastal rahvaluule definitsiooni: "Rahvaluule ehk folkloor on kultuuriliselt kokkukuuluva rühma sünkreetiline pärimus, milles on koos teadmised, kogemused ja esteetika. Rahvaluule kujuneb, püsib ja levib kommunikatsiooniprotsessis ning talle on omane pidev muutumine" (Jaago 1999: 15). Ameerika uurija Simon J. Bronner jälgib rahvaluule mõiste muutumist ajas. Ta pöörab vähem tähelepanu selle kunstilisele mõjule ja toob enam esile rahvaluule argielulisuse, praktikas kasutamise võimalused. Tänapäeval uurivad folkloristid küsimusi, mis on seotud folkloori tähendusega ja sellega, kuidas inimesed end väljendavad (Bronner 2017: 45-47).

Folkloori puhul on läbi aegade rõhutatud kollektiivsust, ent arusaam kollektiivsusest on ajas muutunud. Kuigi rahvaluule suurkoguja Jakob Hurt soovis 19. sajandi lõpupoole anda välja "Kogumise ajaraamatu", mille koostamise tarvis ta palus andmeid koguja ja jutustaja-laulja kohta, ei tähendanud see terviklike elulugude kirjapanekut, vaid vastamist esitatud küsimustele. Saadetud vastuste pikkus jäi enamasti vahemikku 0,5-2 lehekülge (Kikas 2017: 584-586). Osa rahvaluule arhiivi kaastöölistest kirjutasid oma elust ja kogumistööga seonduvast ka omal algatusel (Tamm 2002: 86-88), kuid üksikmälestused ei kuulunud pikka aega folklooriarhiivi kogumishuvi keskmesse ei Soomes ega 


$$
\text { Gerwdiseid islem Bulanist! 39 }
$$

yoige pealt andestoge, et nic racea teie rirja pexle ei vastomid mitme suguste póhjuste pá

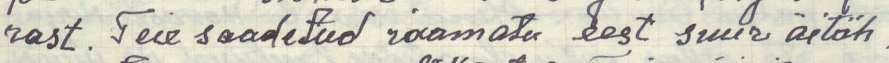
roger feie os awonno for"listele. Jeile kögile muer dicgi ena ofen tumblmata iscre, no ega see asfa es rirec, Iundmata isireed voivad $\mathrm{ka}$ iga sagusi rikis foosi läbi visa, mis ritisitoma ele le rasu toob. Sina ofen fiberis sündirud

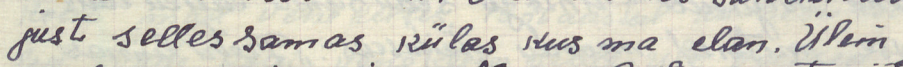
Bulanis. Hina isa Ofsesson Perter Hustavits an sundinced cestes just Fartes linmas, vie orla ina, ot on praregugi Jarties isa sugu. Pasi. Peale saja arstat tagasi misus isa sacoseti Siberisse; Isa nowaris et misisas tos juures, föolised tostsivad tüli, Tüli ajal sai moisa muljas surma. No ja roicie need Töolised tes tirlist osa votsid saadet. Siberesse nemo' hulgas of mines ise. Minu ema' sündis $f^{\prime}$ -

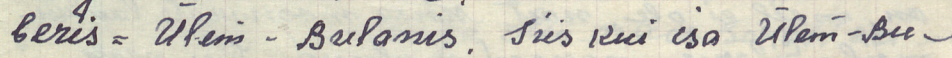
hasuisp tirli, oli seltes sirlas dinult rolnfolu, nende hilgas ita mina ema isa taen. Sün

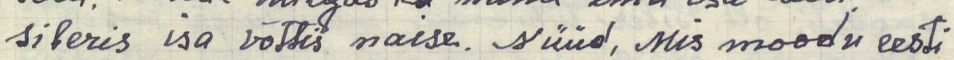
ma lacelud Siberissp said 2 Peale 100 anstat tagasi. Mei harrati cestist inimesi Jiberisse

Foto 1. Ottessoni Roosi kiri kirjandusmuuseumi rahvaluule osakonnale 1969. aastal. RKM II 271, 39.

Eestis (vrd Mikkola 2009: 99, 108). Biograafilisi jutte kasutati rahvaluules eeskätt silmapaistvate laulikute-jutustajate loomingu tausta uurimiseks (vt nt Kõiva 1964; Pentikäinen 1971). Mitmed uurijad, näiteks Maryn Lyons on rõhutanud, et anonüümsete vaeste inimeste elusid on minevikus uuritud kollektiivses vormis. Nad on olnud mass ilma personaalse identiteedita (Lyons 2013: 14, 16). Georges Gusdorfi hinnangul on autobiograafia, mille sisuks on üksikisiku ja tema elu erakordsus, üsna hiline ja spetsiifiliselt Lääne kultuurile omane nähtus (Gusdorf 1980: 29). 
Juri Lotman väidab, et kogu inimmassist, kelle elukäik ei kuulu kirjeldamisele ja kollektiivsesse mällu salvestamisele, valitakse keegi, kelle nimi ja teod säilitatakse järeltulevatele põlvedele. Erandlikkus, mis annab õiguse personaalsele esindatusele kollektiivi mälus, võib varieeruda nii kvantiteedilt kui ka kvaliteedilt. Kvantitatiivses mõttes võib see seisneda antud ühiskonnas iseenesest mitte midagi erandlikku kujutava normi erandlikult täpses täitmises. Kvalitatiivsel hierarhiaredelil saab määravaks käitumistunnuseks normi valik ja koguni indiviidi omalooming käitumisvallas (Lotman 1990: 366, 369).

Individuaalsete mälestuste osatähtsus arhiivides ja uurimustes on kiiresti kasvanud alates 1980. aastaist, see võis muutuda isegi esmaseks kogumisja uurimisobjektiks (Pöysä \& Timonen 2004). Autobiograafilist materjali on vaadeldud kui mina-žanri, milles "kunstnik" sulab ühte "modelleeritavaga" (Gusdorf 1980: 31). Inimene on paratamatult seotud teistega perekondlike, kogukondlike, tööalaste jm sidemete abil. Kuna kogemused ja lood on ühel ajal nii individuaalsed kui ka sotsiaalsed, vahendatakse lugudes omaenda kogemuse kõrval ka oma pere ja kogukonna kogemust. Seega on iga inimese eluloos oma koht ka folklooril. Sotsioloog Maurice Halbwachs (1877-1945) osutab individuaalse ja kollektiivse mälu erinevustele, väites, et inimene meenutab, aga kollektiiv määrab selle, mida on mõtet meenutada ja mida on vaja mäletada (Halbwachs 1992: 50-51).

Tänapäeval pööravad folkloristid üha enam tähelepanu üksikisikule ja tema kultuurikogemusele, see aitab esile tuua kultuuride inimlikku ühisosa. Folklorist lähtub küsitlemisel sageli rahvaluuleliikidest, kuid vastajad toovad esile enesekohasuse, põimivad vastustesse oma elukogemuse. Ja et pärimuskeskkond on elukogemuses loomuldasa olemas, lisandub see teave pärimusekogumise käigus.

\section{Venemaa eestlaste mälestused ja nende vahendamine}

Artikli koostamisel kasutan Venemaal sündinud eestlaste endi kirjapanekuid, põhiliselt aastatest 2002-2005, ja jutustatud mälestusi, mida kogusin enam ajavahemikul 2003-2009. Elulugude ja isiklike mälestuste kogumiseni jõudsin folkloori uurimise kaudu - olin enne seda rohkem kui kümme aastat talletanud Siberi, aga ka teiste Venemaa eesti kogukondade folkloori: laule, rahvajutte, kombestikukirjeldusi jm. Kogutud materjali põhjal olin teadusartiklite kõrval koostanud tekstiantoloogiad Siberi eesti kogukondade folkloorist (sari "Eesti asundused" I-IV ja CD-antoloogia "Siberi eestlaste laulud"), millega olid paljud minu vestluskaaslased tuttavad. 


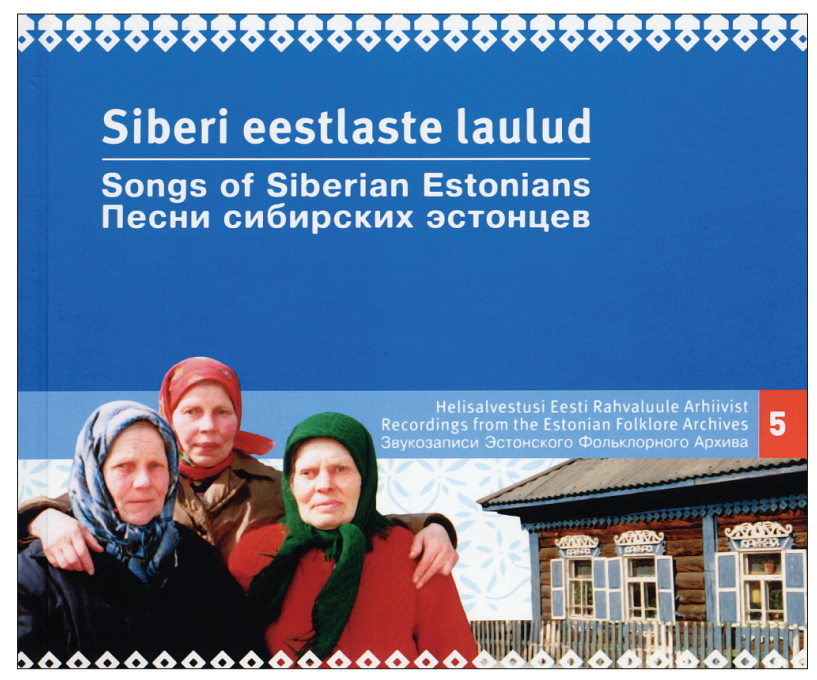

Foto 2. Antoloogia "Siberi eestlaste laulud".

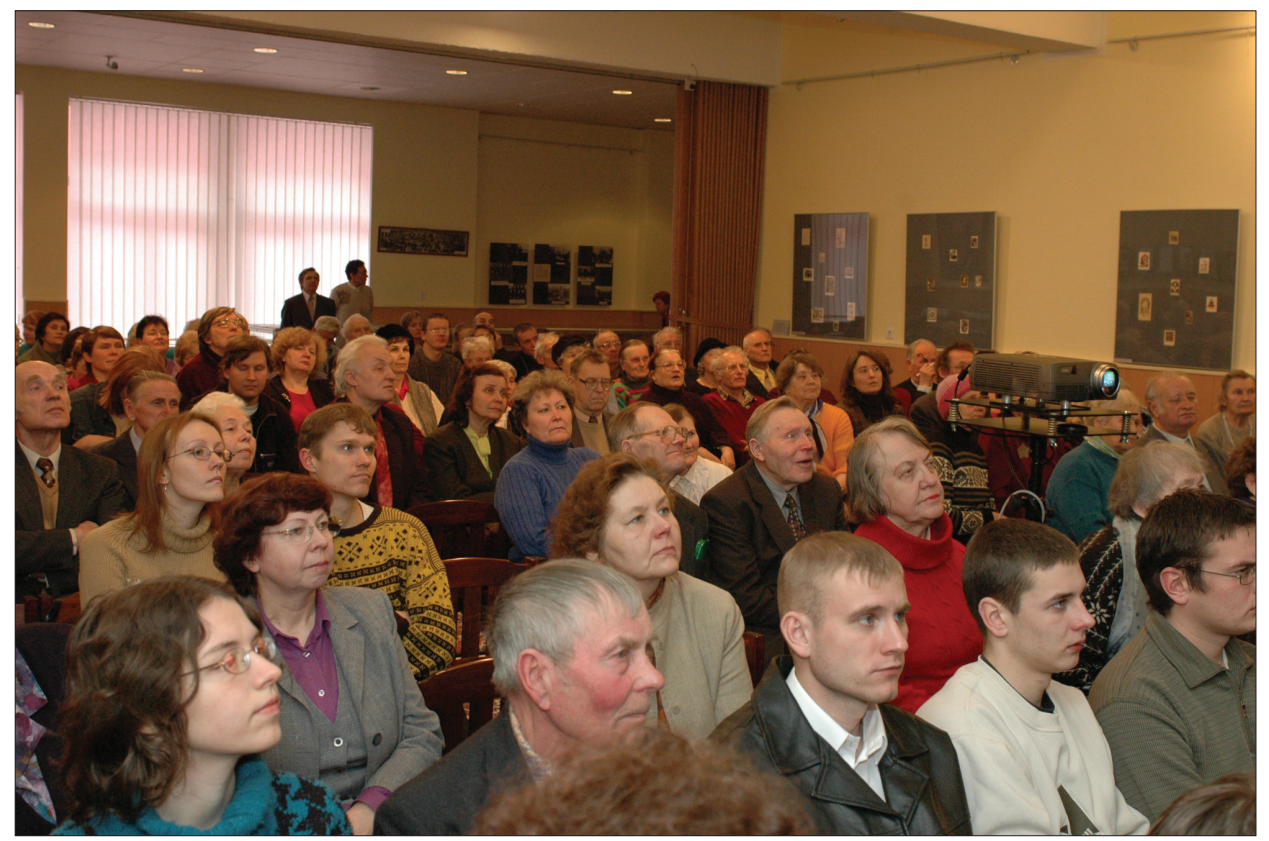

Foto 3. Üritusest "Venemaale veerenud II. Väljarännanute elud ja lood" osavõtjad Eesti Kirjandusmuuseumi saalis 2005. aasta kevadel. Alar Madissoni foto. 
Ehkki tundsin kogumistöö algusaegadel huvi eeskätt pärimuse vastu, jutustasid Venemaal sündinud eestlased meie kohtumiste käigus lugusid ka oma elujuhtumistest. On üsna loomulik, et pärimuskeskkonnas elanud inimese elulugu on folkloorse ainesega tihedalt läbi põimunud. Folkloori kogumise kõrval hakkasin aja jooksul teadlikult eluloolisi mälestusi talletama. Esimesed kontaktid Venemaal sündinud eestlastega Eestis tekkisid mul nende Venemaa sugulaste kaudu, kelle pool olin käinud pärimusekogumise retkedel. Eeskätt neile mõeldes korraldasin Eesti Kirjandusmuuseumis 2003. aasta sügisel esimese teabepäeva "Venemaale veerenud" (vt Korb 2003a: 267-272), kus tutvustasime huvilistele Siberist jm Venemaalt Eesti Rahvaluule Arhiivi kogutut ja kutsusime inimesi üles oma pere- ja külalugusid kirja panema. ${ }^{2}$ Osa inimesi, kellele teksti kirjapanemine raskusi valmistas, pöördusid ise minu poole, et mina nende lood talletaksin. Nii käisingi inimeste mälestusi salvestamas, mõned salvestused tegi 2009. aastal ka Maarja Aigro. Edaspidi toimus kogumine lumepallimeetodi abil - mulle juhatati aina uusi inimesi, kes võiksid oma elust jutustada. Enam kogusin Venemaa eestlaste lugusid Eestis ajavahemikul 2003-2009. Küsitluste keskmes olid esivanemate väljarändamine ja elu sisseseadmine võõrsil, haridusja kultuurielu, eestlaste argielu ja tähtpäevad talude perioodil ja pärast kol-

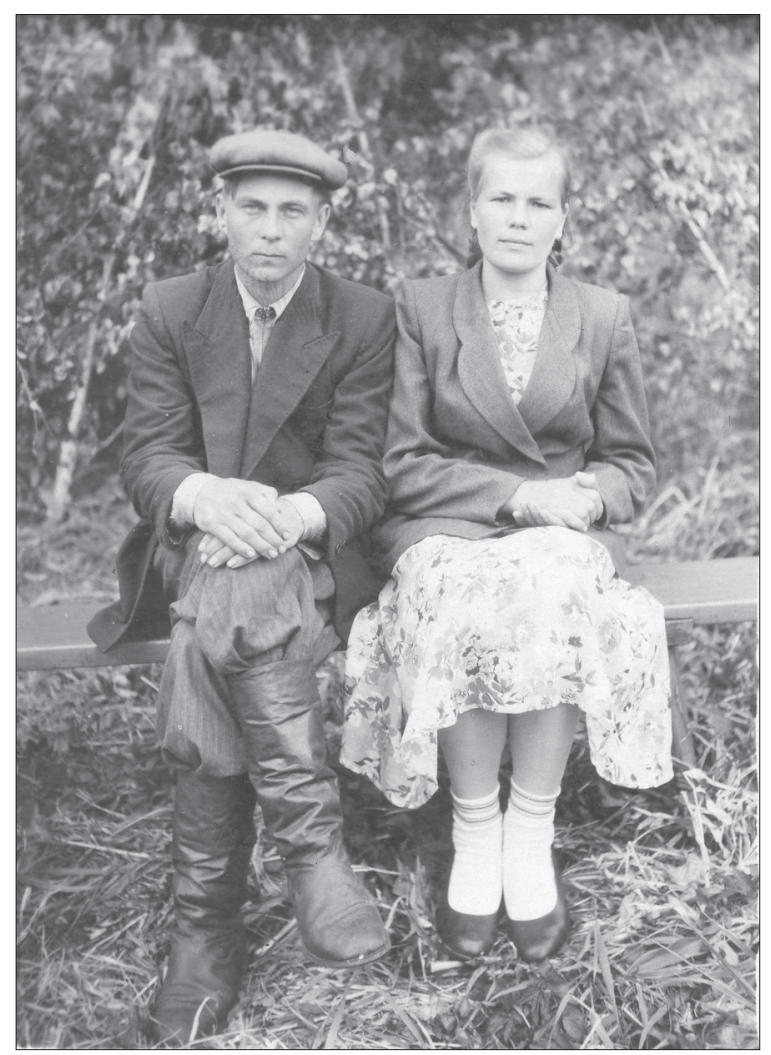

lektiviseerimist, pöördelised ajaloosündmused, emamaale naasmine ja siin kohanemine. ${ }^{3}$ Põhiosa jutuajamisi toimus minu vestluskaaslaste kodudes, toeks perefotod, alal hoitud dokumendid, mõnikord ka vanad esemed. Püüdsin vestluse käiku küsimusi esitades juhtida, kuid samas lasin inimestel rääkida neile olulisest. Mõned küsitlused Eestis viisin läbi ka külavõi piirkondlikel kokkutulekutel vm avalikes kohtades (nt kohvik) ning need jäid seetõttu põgusaiks.

Foto 4. Alviine ja Karl Veeber 1955. aastal Kemerovo oblasti Koltsovo külas. Foto eraarhiivist. 
21. sajandi esimene kümnend oli Eestis Venemaa eestlaste lugude kogumiseks igati sobiv: leidus piisavalt inimesi, kes võisid olnust jutustada; avalikkuse huvi Venemaa eestlaste vastu oli kasvanud; varem tabuks peetud teemasid käsitleti julgemini. Venemaal sündinud eestlased, kes naasid nõukogude päevil Eestisse, kohtasid Eestis erineva kultuuritausta, tavade-kommete, aga ka eelarvamuste tõttu tõrjuvat suhtumist ja püüdsid aastakümnete vältel üldsuse eest oma päritolu varjata. Nemadki arvasid, et parem on kaotada omapära võimalikult kiiresti (vrd Roos 2000: 91). Pärast Teist maailmasõda ei toetanud ka välistegurid suguvõsaajalooga tegelemist - see valdkond jäi pere raames ja pere jaoks jutustamiseks (Jaago 2003a: 35). Avalikumalt hakkasid Venemaal sündinud eestlased oma isiklikke lugusid rääkima 1980. aastate lõpupoole, kui selleks tekkis valmisolek nii grupisiseselt kui ka ühiskonnas tervikuna. Mõneti on see seotud ka Ida-Euroopas lahvatanud "biograafilise buumiga" (Humphrey \& Miller \& Zdravomyslova 2003). Elulooteksti (nii suulise kui ka kirjaliku) loomises on seotud nii jutustatava sündmuse aeg, jutustamise aeg kui ka sinna vahele jääv aegruum oma muutumises (Jaago 2001: 9 jj). Aili Aarelaid-Tart (2009: 172, 179) toob esile ajakategooria kultuurimuutuste mõistmisel, tõdedes, et pole olemas üht ja ainuvaldavat ajavoolu, kultuurimälu vahendusel toimib minevikukogemuse ülekandmine olevikule. Suurte poliitiliste pöörete tulemusena muudetakse riiklikul tasemel minevikusündmuste aktsentueeritust, reglementeeritakse unustamisele määratu. Eesti Vabariigi taastamine ja tsensuuri lõdvenemine Venemaal olid elu- ja pärimuslugude esile kerkimise eelduseks. Ene Kõresaar (2005: 21) on osutanud mälestuste ja elulugude avalikule rollile Eesti taasiseseisvumise perioodil. Samas leidus Venemaal sündinud eestlaste hulgas ka neid, kes omaaegsete solvumiste, negatiivsete mälestuste vms tõttu ei soostunud põhimõtteliselt Eestimaa eestlastele oma elust rääkima. Kuigi ideoloogilised tagasirändajad moodustasid väikese vähemuse kõigist Nõukogude Liidust saabunutest, tekitasid nad Eestis mitmeks kümnendiks idadiasporaast negatiivse kuvandi (Tammaru \& Kumer-Haukanõmm \& Anniste 2010: 44).

Mõistagi erinevad kirjapandud lood ja spontaanses jutustamisõhkkonnas salvestatu. Elulookirjutajatel on võimalik oma lugu enam läbi mõelda ja viimistleda, jutustatud lugu sõltub suuresti kuulajaskonnast, see esitatakse situatiivselt ja tsükliliselt. Satu Apo (1995) pakub teksti kirjaliku esituse kohta välja mõisted "teemakirjutamine" ja "kirjutav jutustaja".

Jyrki Pöysä (2009: 40) toob välja kirjaliku ja suulise esitusviisi erinevuste mõju materjali tõlgendamisele. Ta peab oluliseks asjaolu, et tegemist on kirjutada palutud, mitte juba olemasolevate tekstidega. Kui intervjueerimise üheks väärtuseks on peetud isiklikku kokkupuudet informantide ja nende elukeskkonnaga, empaatilist lugupidamist vestluskaaslase vastu, siis enesekohast kogemust saab kirjeldada ilma vahetu kontaktita koguja ja informandi vahel. 
Kirjutades meenutamise keskseks jooneks on privaatsus, otsese interaktiivse suunamise puudumine, suurem vabadus valida oma kirjutamissuunda, võimalus teksti muuta ja täiendada jm. Samas on kirjutise jutustavaid vorme raske määrata ja üksteisest eristada (Pöysä 2009: 42-45, 49). Enda kogutud materjali puhul pean tõdema, et ka kirjapandud lood olid suuresti minu suunatud - üleskutsele lisaks olin koostanud ka küsitluskava, millele võis vajadusel toetuda. Mõistagi panid osa inimesi oma loo kirja küsitluskava jälgimata. Mõnd kirjatöö saatnut käisin hiljem lisaks intervjueerimas, nii sain nende kirjapandut täiendada-täpsustada.

Venemaal sündinud ja kasvanud eestlaste lapsepõlves omandatud teadmised, kombed ja traditsioonid, aga ka ajas muutuv sotsiaalne ja looduslik keskkond mõjutab paratamatult kogu inimese elu ning leiab koha ka eluloolistes mälestustes. Kogemus on individuaalne, aga oma kogemusi jagatakse teistega sellest jutustamise abil. Jutustuse kaudu mõjutatakse lokaalset traditsiooni, individuaalse elu fakt võib muutuda sotsiaalseks kogemuseks (vt Laagus 2009: 115, 121). Samas olid minu küsitletavad aastaid tagasi lahkunud kogukonnast, kus nad olid sündinud-kasvanud, ja rajanud oma uue kodu Eestis. Sidemed oma kodukülaga Venemaal ja sealt pärit inimestega Eestis olid neile aga äärmiselt olulised.

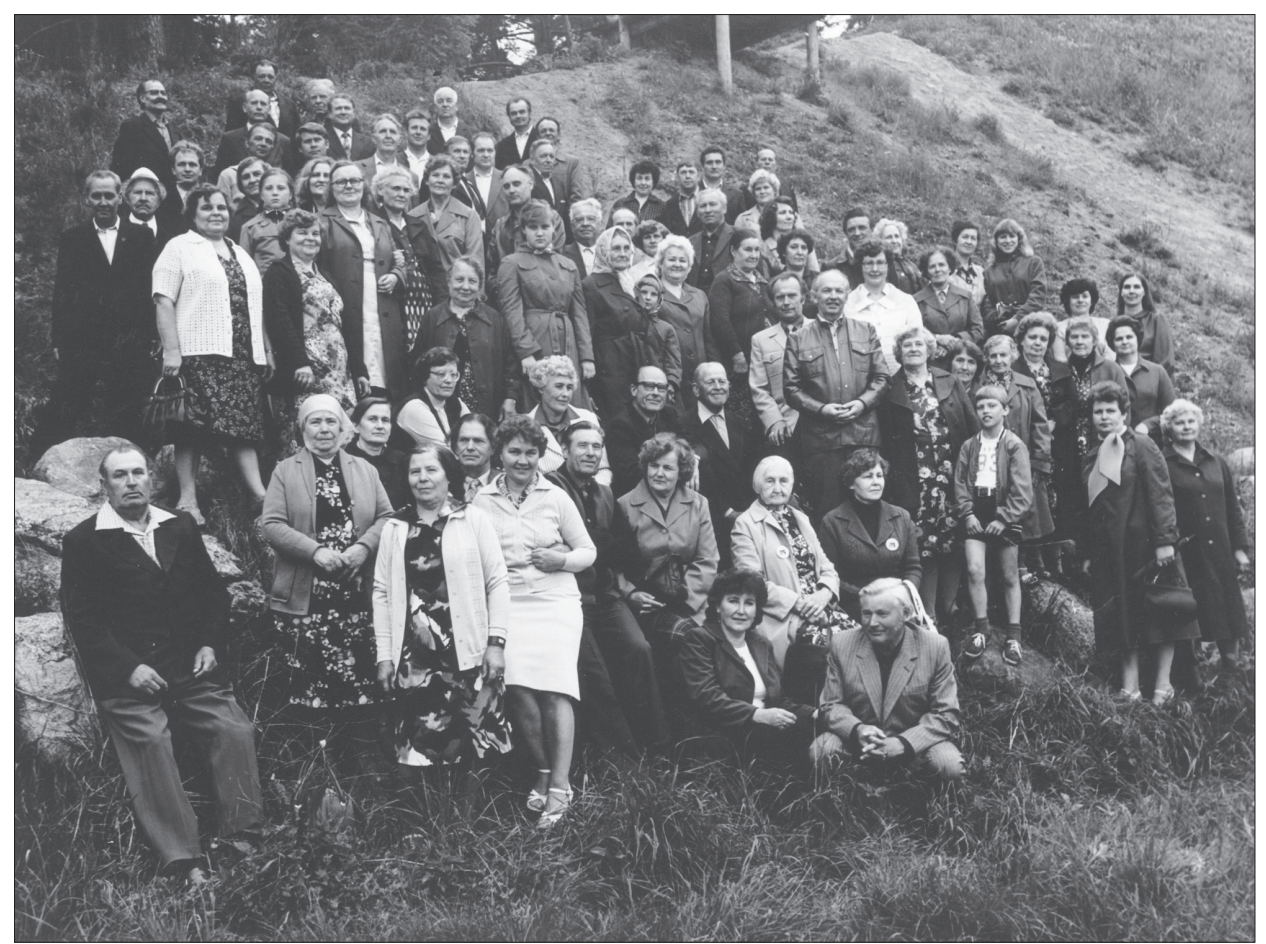

Foto 5. Samaara eestlaste kokkutulek Tallinna lähistel Pirita jõekäärus 1983. a. ERA, Foto 17187. 


\section{Teemad, millest jutustatakse}

Venemaal sündinud ja kasvanud eestlaste mälestustest valisin analüüsiaineks teemad: 1) esivanemate päritolu- ja nimelood, 2) võõrsil uue kodu rajamisega seonduv, 3) pöördelised ajaloosündmused pere- ja kogukonna elus, 4) eluringi tähtsündmused. Samas ei saa neid teemasid üksteisest jäigalt eraldada, sest neil on üksjagu kokkupuutepunkte.

\section{Esivanemate päritolu ja nimelood}

Venemaa kogumismatkadel, aga ka Eestis Venemaal sündinud-kasvanud inimestega juttu vestes oli hea alustada sellest, kuidas jutustaja esivanemad Venemaale elama sattusid. Nii jõudsin perekonna või kogukonna traditsiooni talletamiseni, mille kohta Eesti folkloristikas on kasutatud mõistet pärimuslik ajalugu. Tiiu Jaago (2006) on terminit seletanud järgmiselt: "Pärimuslik ajalugu kujuneb minevikust ja ajaloosündmustest jutustamisel, milles ühelt poolt väljendub kas iseenda või oma lähedaste (nn oma rühma) tõsielukogemus ning teiselt poolt olemasolev pärimuslik jutu- ja jutustamistraditsioon.” Jutud oma päritolust ja esivanematest aitavad inimesel hoida identiteeti, määratleda oma kohta ajaloos. Astrid Tuisk (2011: 57) tõdeb Siberi eestlaste väljarändamisjuttude analüüsi põhjal, et neid tekste ei saa mahutada ühe konkreetse folkloorižanri alla, neid võib vaadelda kui pärimusliku ajaloo üht perioodi kirjeldavat "lugu", mis põhineb rühma üldisemal minevikukäsitlusel. Nii tekstid kui ka käsitlused luuakse olemasolevate kultuuriliste normide ja oskuste abil (vt ka Latvala 2005: 71-79). Mõisalegende uurinud Mari-Ann Remmel märgib, et mida vanemast ajast jutt, seda vähem detaile ja konkreetsust. Samas mängib iga teksti puhul kaasa jutustamise või üleskirjutamise aja keskkond ja ideoloogia (Remmel 2008: 25).

Nagu Eesti traditsioonis, nii kajastub ka Venemaa eestlaste päritolujuttudes mõisaaeg Eestis.

Sageli jutustatakse Siberi eestlaste lugudes mõisnike tehtud ülekohtust, millest saab alguse elu võõrsil - Siberis.

Vanaema oli sakstel toatüdrukuks, a vanaisa oli tallipoiss. Kaks väikest last oli. Oli veikene rinnalaps üks, a teine oli suurem. Mõisnikud pidasid palju koerasid. Panivad seda vanaema imetama kutsikuid. No mees tuli ôhta kodu ja laps nutab, a kutsikatele imetas ära piima. "Mikspärast laps nutab?" - "Näe, peremees tõi kutsikaid siia, a oma laps on nälgas." A vanaisa võttis ja poos need kutsikad ära. Mõtles, et tuleb, mis tuleb, a Jumal kah seda ei kiida, et kutsikaid peab söötma nagu loom. Sai 
25 hoopi selle eest ja saadeti Siberi. (Omski obl, Vana-Viru k < naine, snd 1923 (salvestatud 1997))

Kutsikate (ka vananeva mõisniku) imetamise motiiv on ajaloolises pärimuses üldlevinud ning ses suhtes võrreldav inimeste koerte vastu vahetamisega. Ka Eestimaa eri piirkondadest on läbi aegade analoogilisi lugusid talletatud, neid leidub rahvaluule arhiivis nii Jakob Hurda vanavarakogus $(\mathrm{H})$ kui ka märksa hilisemates rahvaluulekogudes - ERA ja RKM. (Vt nt H II 36, 747/8 (73) < Vaivara khk ja v; ERA II 255, 628/9 (1) < Kaarma khk ja v (1939); RKM II 22, 75 (1) < Räpina khk, Kahkva v (1949); vt ka Remmel 2008: 215). Paljudes lugudes tuleb esile mehe vastuhakk mõisnikule - kutsikate, ka mõisniku tapmine. Vaenulik hoiak mõisnikesse ja üldse sakstesse ja härradesse avaldub ka muudes folklooritekstides (vt Tuisk 2011: 61; Valk 2008: 64-66).

Järgnevas, Eestis talletatud pereloos ei mäletata enam esivanemate väljasaatmise põhjust, kuid säilinud on teadmine, et nad on olnud Siberisse saadetud.

Minu emapoolne vanaisa oli mulk, Nopassoni-nimeline. Temal olid vanemad ära surnud ja onu kasvatas teda. Onu elas Tartu kandis. Vanaema oli Nopassoni Juuli, tüdrukust peast oli ta perekonnanimi Rebane. Minu vanaema oli õppinud loomi tohterdama, ta oli Karlova mõisas loomaarst. Vanaisa ja vanaema on Võnnu kirikus laulatatud ja nende kolm last on seal ristitud. Mingi asi juhtus mõisas ja minu vanaisa saadeti sellepärast eluks ajaks Siberisse. Pärast saadeti vanaema takka järele. (Harjumaa, Salutaguse k < Krasnojarski krai, Ülem-Suetuki k < naine, snd $1917(2003))$

Siberil on läbi aegade olnud halb kuulsus, seda on peetud eelkõige väljasaatmise ja sunnitööpaigaks. Tegelikult moodustasid väljasaadetud 19. sajandi lõpul ainult 5\% Siberi ligi kuuemiljonilisest elanikkonnast (Wood 1991: 118).

Mõisa ja mõisnikega seonduvad jutud on oma koha leidnud ka väljarännanute perepärimuses, kuigi väljarändamise kõrgperioodil 19. sajandi lõpul ja 20. sajandi algul oli Eesti- ja Liivimaal aktuaalne hoopis talude päriseks ostmine (Rosenberg 2010: 104-109). Väljarännanute perelugudes kirjeldatakse esivanemate väljarändamist kui vabanemist mõisaorjusest, püüdu vabama elu ja oma maa poole. Esile tuuakse kurnav vähetasuv töö mõisas, ka laste töölerakendamine ning mõisniku ihnus ja omakasupüüdlikkus sealjuures:

Isapoolsed sugulased on pärit Lasva vallast Kõo külast. Minu vanaema, isaema, on sündinud 1870. aastal, tema oli 38-aastane, kui nad Venemaale läksid. Tema lapsed olid kõik Eestis sündinud, kolm last, kõige vanem oli 14 ja minu isa oli noorim, kolme-aastane. Eks nad tahtsid ikka oma talu saada. Vanaema oli väga ladusa jutuga, elas meiega koos ja kogu aeg 
jutustas. Ta rääkis ka mõisaajast. See oli Eestimaal, siis kui vanaema veel laps oli. Mõisas oli lastele ka tööd antud - marju korjata. Lapsed pidid pulgad suus hoidma, et nad marju ära ei sööks. Ja hiljem pidid lapsed marjakorjamise ajal laulma. Kellel aga laul vaiki jäi, sellele oli kubjas kohe teinud märkuse. (Võrumaa, Väimela v < Kirovi obl, Oparino raj < naine, snd 1933 (2005))

Kirjapanekuid ihnsatest mõisnikest võib Eesti Rahvaluule Arhiivi kogudest leida üksjagu. Konkreetse Venemaa eestlaste looga haakub näiteks Rõuge kihelkonnast talletatud jutt sellest, kuidas töölistele, kes pidid Viitina mõisa hernepõllu kokku panema, seotud rätid suu ette, et nad töö ajal ei saaks herneid süüa (vt ERA II 244, 396/7 < Rõuge, Laitsna-Ragosi v (1939)).

Esivanemate kitsikuses elamist Eestis rõhutatakse kujundlike võtete abil.

Eestis nad elasid rehetoas, see olnud nii väike, et lapse häll oli vanemate voodi kohal, söögilaud, ja muud mitte midagi neil ei olnud. Nemad elasid Rõngus, olid mõisa teenijad. Eestis oli neil ainult üks kana ja see kah nööri otsas, ei olnud jalatäit kuskil oma maad. Ja mõisas perenaine oli ütelnud, et su kana vaatab juba minu kapsaaeda. Vanaema oli tolle peale väga solvunud. Siberis oli vähemalt maa. (Tartu $1<$ Kemerovo obl, Koltsovo k < naine, snd 1929 (2003))

Väljarännanutele, kellele sageli kodumaa reetmist ette heideti (Jürgenson 2002: 46), oli enesetunde tõstmiseks kahtlemata vaja näidata väljarändamist kui paratamatust, väljapääsu viletsusest.

Kuigi enam kujutatakse lugudes mõisnikke ja saksu kurjuse kehastusena, võib pärimusest leida jutte ka headest sakstest (vt Remmel 2008: 37-38). Üheks positiivseks jutukangelaseks on Sangaste krahv, kes hoolitsenud oma tööliste eest, pidanud Siberisse väljarännanud talupoegadega kirjavahetust ja aidanud neid igati (vt EAA 1871.1.1705). Mees, kes oli teadlik oma Sangaste juurtest, rääkis oma elulooliste mälestuste meenutamise käigus loo Sangaste krahvist:

Vanaisa oli Sangastest, tema oli viil - viinapruulis tü̈̈tas. Sangaste krahv $v^{4}$ oli hea miis ikka nende töölistele, oli kiiduväärt inimene. Tal oli kari ja põldu ja viinavabrikud.

Kuidas [Sangaste krahv] haige oli ja end viinatünnides arstis, praagatünnides enne läbiajamist. Tal oli kondimurdja-haigus, nii kõvasti valutab konte, a välja arstis. Praak lasti tünni sisse. Ja oli kogu kerega sees, nii palju kui kannatas. Kui juba nõrgass võttis, siss sai tervess. Ja Sangaste krahv ise ütles, et vaata, et te viinapruulidele ära ei räägi seda arstimist, et rahvas ju joob seda viina. (Omski obl, Zolotaja Niva $\mathrm{k}<$ mees, snd 1921 (1995)) 
Sangaste krahvi rahvapärast arstimislugu - rahvameditsiinis on viinal tähtis koht liigestehaiguste ravis (vt nt Kõivupuu 2013: 188) - võime vaadelda kui rahvajuttu. Seos konkreetse ajaloolise isikuga aitab esivanemate päritolupaika järeltulijate mälus kinnistada.

Eestis Venemaal sündinud eestlastelt kuuldud lugudes võib kohata ka neutraalset suhtumist sakstesse, ka seda, et mõned neist keelitanud peret Siberisse-minekust loobuma: mida sa arvad sealt head leidvat, lähed vaid naisi ja lapsi sinna suretama. (Ida-Virumaa, Purtse k < Tomski obl, Kaseküla < naine, snd 1939 (2004))

Samas märgivad jutustajad, et väljarändajad olid oma otsuse teinud ja jäid sellele kindlaks.

Tihtipeale liituvad esivanemate päritolulugudega meenutused perenimede panemisest.

Minu isapoolsed sugulased olid kuskilt Narva kandist. Isa nimi oli Juhan Miller, vanaisa oli Joosep ja vanaema oli Arina. Vot seda vanaema ma nägin - Arinat. Ja mulle jäi veel meelde, papa rääkis, et mõisnik, kes temale meeldis, sellele ta andis ilusa perekonnanime, aga kes ei meeldinud, sellele andis inetu nime. (Põltsamaa l < Krasnojarski krai, Ülem-Suetuki k $<$ naine, snd 1931 (2009))

Venemaale väljarändamise ajaks olid eestlastel perenimed olemas, üldine perenimede panek sai alguse varsti pärast Eestimaa ja Liivimaa talupoegade pärisorjusest vabastamist. Ma-Rahwa Näddala-Lehe väljaandja Otto Wilhelm Masing jaganud rahvale õpetusi, milliseid nimesid talupojad peaksid valima (vt Must 2000: 51-55). Aadu Must märgib, et rahvatraditsioon kaldub väitma, et piirkonniti olnud nimede panemisel suuri erinevusi. Mõnel pool olid sellega tegelenud mõisnikud, teisal opmanid või kirikuõpetajad. A. Musta hinnangul viitavad sarnase mudeli järgi pandud kogu kihelkonna ühtlased nimed pastori olulisele osale nimede panekul. Kui kihelkonna mõne mõisa nimed hiilgavad aga omapärasusega, tasub autorit otsida mõisniku perest või mõisa ametimeeste hulgast (samas: 55-56).

Mõni jutustaja ei oska täpselt oma esivanemate nime päritolu seletada, on kuulnud lihtsalt:

Isapoolsed vanavanemad olid Nilenderi-nimelised. Nilender, kes ütleb, et see on rootsi nimi, kes ütleb, et on saksa nimi. Nilenderi Madli oli olnud Tapalt, aga Nilenderi Taavet ise oli päris Tallinnast. Ta oli ikka laulnud, et tema on Tallinnast tulnud ja pudeli puhuja, klaasivabrikust ta oli väljagi saadetud. (Tallinn < Krasnojarski krai, Ülem-Suetuki k < naine, snd 1917 (2009)) 
Mõnikord teatakse jutustada ka esivanemate hüüdnime saamisest:

Kui minu isa vanemad Siberisse tulid, savikallas, mis seal kiriku all on, minu esivanemad tegid sinna savikaldasse koopa, kus nad siis elasid niikaua kui maja ehitasid. Hakkasidki hüüdma isa vanemaid Kalda Liisu ja Kalda Joosep, aga perekonnanimi oli Miller. (Põltsamaa l < Krasnojarski krai, Ülem-Suetuki k < naine, snd 1931 (2009))

Osa talletatud jutte on lihtsalt mälestused, rahvapärased ajalootõlgendused, uskumusteated vms. Tiiu ja Kalev Jaago (1996: 128) on tõdenud perepärimuse uurimise põhjal, et päritolujuttudes on teave väga oluline ning see peab saama jutuvormi, et traditsioonis püsida. Tugeva peretraditsiooni korral on teadmine esivanematest enamasti detailirohkem ja informatiivsem. Venemaa eestlaste esivanemate päritolu- ja nimelugudes kajastub ootuspäraselt mõisaaeg. Enamasti nähakse mõisnikku rõhujana, kelle võimu alt pääsemiseks võõrsil uus kodu rajatakse. Salvestunud on kodukohateadmine, esivanemate nimed ja peetud ametid.

\section{Teekond, kohanemine uues elupaigas ja kohanimelood}

Väljarännanute jõudmine uude elupaika on ühtlasi piiri ületamine nii tulijatele kui ka varem selles paigas elanuile (Jürgenson 2002: 25-57). Varasematel tulijatel tundub olevat uues paigas enam õigusi. Seetõttu on kandepinda lugudel, mis räägivad paiga asutajaist, esimestest elanikest (vt ka Tuisk 2001: 80-82).

Kui Ülem-Suetuki küla asutajast ja asutamisest teame arhiiviandmete põhjal, et küla asutaja, väljasaadetud eestlane Jüri Kuldmäe, pärit Põltsamaalt, jõudis esmalt Tobolskisse, siis Rõžkovosse, sealt edasi Tšistaja külla. Kuulnud tsaari ukaasist ja Minussinski maadest, asus ta ühes mõne soome perega teele ja ehitas endale maja asustamata paika Suetuki jõe äärde (Viikberg 1988: 286). Perepärimusse kuuluv Siberis talletatud lugu kirjeldab Suetuki küla asutajat ja asutamist järgmiselt:

Minu vanamamma vanaisa kõige esimeseks alustas selle küla. Jüri oli nimi. Ta oli neli aastat tulnd. Mõisa all oli see vana-Jüri tüöl Eestis, rukist lõikamas. Siis ta pü̈̈dis iga kümne vihu tagant suitsetada. Ja see kümnik tuli ja lõi teda ja ta lõi seda kümnikut tagasi. Ja siis teda pekseti ja saadeti ta ära tühja Siberi. No tal oli seal naine ja kaks last, aga neid ei lubatud tal siia tuua. Ta tuli niikaugele kui Omski. Ja seal ta akkas siss tienima omale rahakopikast. Ja siss tienis seal niikaua, kui ta sai omale obuse ja vankre ja hobuseriistad ja raha, kellega tulla sai. Ja seal oli üks eesti naine. Siis ta tuli sellega siia. Ta akkas siia tulema, 
tuli läbi Znaamenkad ja Tubenskid ja talle kuskile ei passind. Ta tuli päris tühja nurka siia. Siis pereulka nurga peal vaatas ringi. Igalt poolt tulivad allikad, seitse allikat. Ja siis ta jäi sõnna seisma ja ta oli üteld, et siin on ea maa, hakkame siin elama. [---] Ei old neid tikkusi kuskiltki saada. Siis temal oli tehtud senna kaldasse suur auk ja pani aga puid sinna sisse. [---] No siis käisivad neid soojasi tukkisi sealt võtmas. Noja lõpuks jäigi Suetuk küla nimeks. (Krasnojarski krai, Ülem-Suetuki k $<$ naine, snd 1924 (1992))

Jutustaja annab siin ajaraami - lugu jutustatakse esivanemast viis põlve tagasi. Jutust leiame viite ülejõukäivale mõisatööle ja mõisas mõistetud karistusele peks ja väljasaatmine -, Siberisse jõudmise teekonnale, lõpust leiame asustusloo koos paigale nime saamise seletusega.

Eestist talletatud samast külast pärit jutustaja pereloos keskendutakse vaid paiganime muutumisele, seda esitatakse mitte kindla teadmisena vaid pigem kui kuulujuttu:

Meie küla oli esiteks ju Kamennõi brot ${ }^{5}$. Kui Tartust käisid kirjad vanamammale ja vanapapale, oli aadress Kamennõi brod - vene keeles Kiviküla või -jõgi, mis ta pidi olema. Kes selle nime Suetuk pani või kust see nimi tuli, ei tea. Mõni räägib, et leidsid sooja tuki koha. (Tallinn < Krasnojarski krai, Ülem-Suetuki k < naine, snd 1917 (2009))

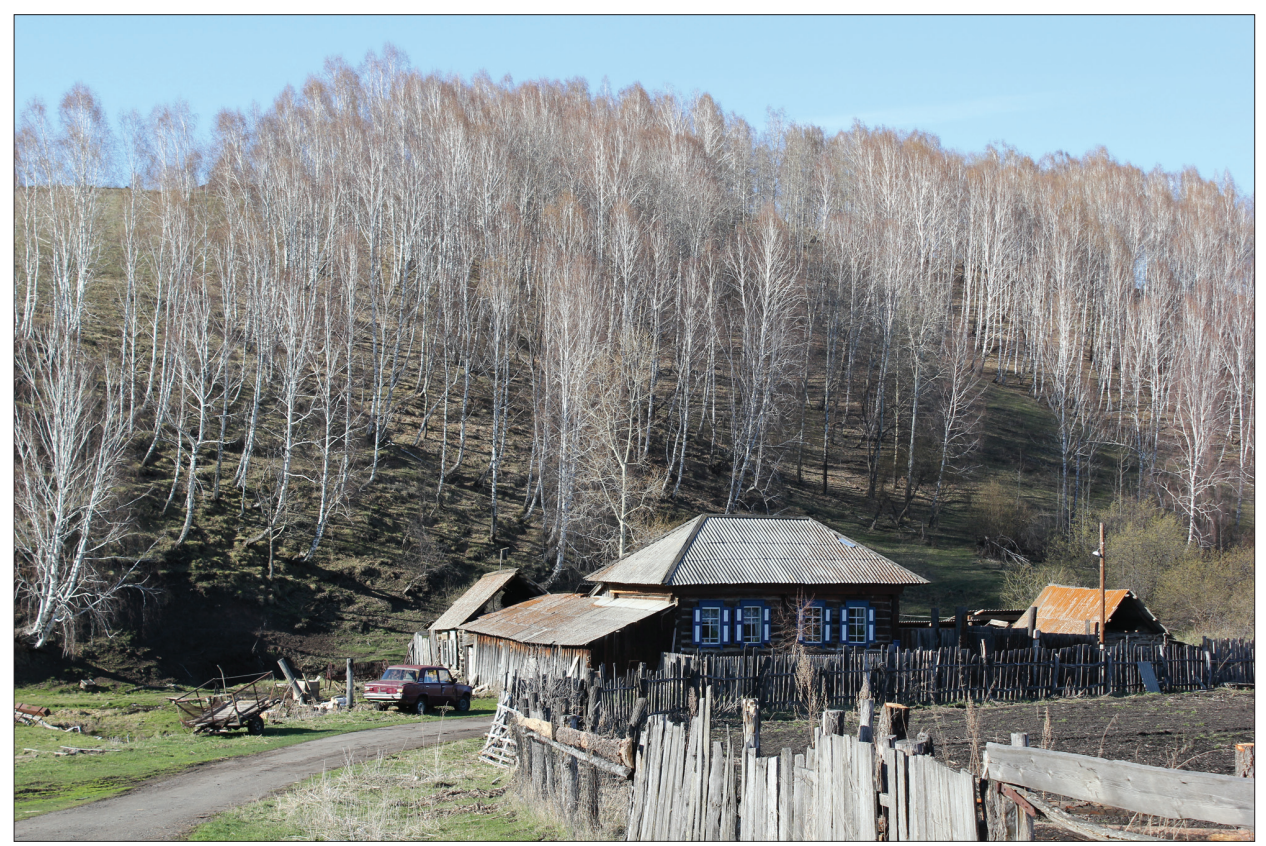

Foto 6. Vaade Vana-Jüri mäele. Ülem-Suetuki küla. Andreas Kalkuni foto 2012. 
Kaugetest aegadest ei suuda mälu jutusüžeid moodustanud detaile lõpmata kaua meeles hoida. Varasematest aegadest meenuvad tavaliselt kõige olulisemad momendid. Kui jutt ise on ununenud, võib säilida ainult teade.

Väljarännanute järglaste lugudes leidub ka teekonnakirjeldusi, kuid enam jääb kõlama esivanemate vaba maa ihalus.

1895. aastal, isa oli nelja-aastane, asusid nad hobustega teele ja jõudsid Gatšinasse Leningradi oblastis. Seal nad vist paar kuud olid paigal. Ma ei tea, kas nad teenisid seal raha natuke ja said toitu, kosutasid hobuseid. Kui nad Eestist läksid, oli tsaariaeg, rahad olid kuldrublad vist ja nad oma raha ei raatsinud raisata. Neile soovitati, et Siberis on vabalt maad saada. Teenisid natuke aega ja läksid jälle edasi. Jõudsid aurujõul Uuralitesse. Uuralite juures soovitati, et minge aga edasi, taga Siberis on vaba maad küll. Ma ei mäleta, kas see oli Novosibirsk juba, kus nad peatusid natuke aega, ja kõik soovitasid: minge aga edasi, seal ise valite endile välja, missugust maad ja kui palju tahate. Ja isa vanemad läksid, Tomskist edasi oli Tšulõmi jõgi, üks Obi haru. See oli 150 meetrit lai, kaunis kiire vooluga, paatidega veeti nad üle. Ja tulid jälle edasi niikaua, kui saidki sinna taigasse. No seal oli põlismets, pidi olema nii, et üle neljasaja kilomeetri on kogu aeg taiga. Seal olid nisukesed väiksed metsatukad, kuhu nemad siis jäid. Igaüks valis ise koha, majad ehitati kõik kruntide peale. (Tallinn < Tomski obl, Liliengofi k < mees, snd 1929 (2004))

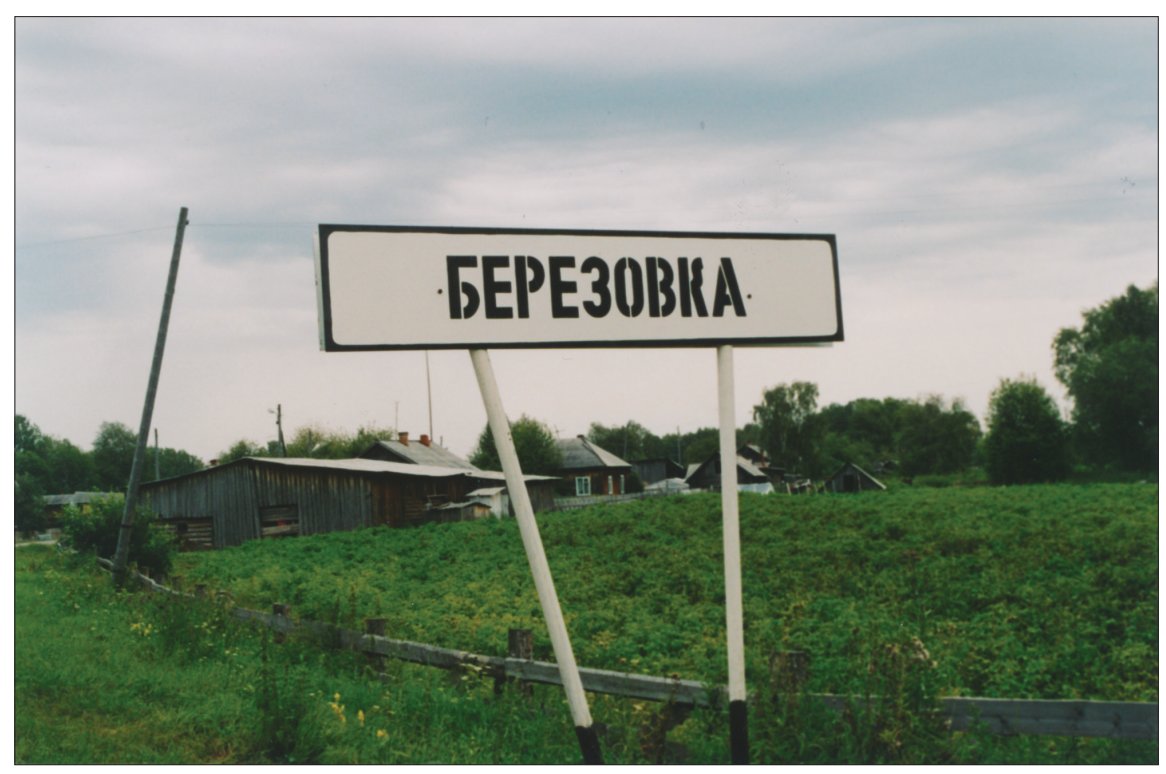

Foto 7. Kaseküla vaade. Anu Korbi foto 2004. ERA, VF 6410. 
Väljarännanute järglaste mällu on juurdunud teadmine, et esivanemad asusid elama seni asustamata maadele ja said vabalt elukoha valida. Tegelikult oli siiski tegemist tsaarivalitsuse poolt suunatud aktsiooniga.

Aivar Jürgenson märgib, et kohanemine uues elupaigas tähendab võõra keskkonna vastuvõtmist omaenese ellu (vt Jürgenson 2002: 25-57). Sellele aitab kaasa uue elupaiga nimetamine endise kodumaa või täpsema päritolupaiga järgi.

Vormsi oli Koltsovost umbes 20 meetrit, üle sihi läksid, olidki Vormsis. Seal oli vast 15 peret, Köörnad olid sealt Vormsi saare pealt ja nad panid oma kodusaare järgi nime. (Tartu $1<$ Kemerovo obl, Koltsovo $\mathrm{k}<$ mees, snd 1928 (2003))

Koltsovo küla nimesaamist aga seletab rahvasuu elanike päritolupaiga $R \tilde{n}$ ngu tõlkimisega sõna 'rõngas' abil:

No algul ei olnud seda nime ega midagi. Siis nad ise pandsid selle nime, et kui nad Rõngust olid pärit, et siis nagu rõngas, nende küla pidi nagu rõngas olema. No ja siis nad viisid vene keele peale üle, et kaltsoo. (Tartu 1 < Kemerovo obl, Koltsovo k < naine, snd 1929 (2003))

Mikrotoponüümika tuli kohapeal luua ja nii tähistati lähiümbrust seal tegutsenud eestlasest maavaldaja nimega (vt ka Tuisk 2001: 80-88).

Meil heinamaad olid viletsad, logakohad, kus õiget heina ei olnudki. Neid kohti kutsuti peremeeste nimedega. Seal tagapool oli Aversoni stepp, meie vanapapal oli Nopasse küür, Kadi Karla kü̈̈r oli siit külast minna kohe. Papi järv oli seal Papi mäe juures, siis oli Vaarmani järv ja Vaarmani veski. Ja külast väljas oli Leeri järv. Leeri Peeter oli seal veski peremees ja oli selle nimega järv ka. (Tallinn < Krasnojarski krai, Ülem-Suetuki k < naine, snd 1917 (2009))

Venemaa küladest Eestisse elama asunud eestlaste asustusloo tundmine on võrreldes oma Venemaal elavate eakaaslastega mõnevõrra nõrgem, sest neil puudus lugude talletamise ajal otsene kontakt paikadega, millest lood räägivad. Inimeste mälus on säilinud teadmine, et Venemaale rännati maapuuduse tõttu ja et Siberis, kus oli palju vaba maad, võis endale ise meelepärase maatüki välja valida. Rännuteekonna kirjeldused on enamasti napid.

Väljarännanute lugudes eksponeeritud teadmist, et paik, kuhu elama asuti, oli enne nende kohale jõudmist asustamata, tühi ja metsik, aitavad kinnistada metsiku looduse kirjeldused:

Siin oli enne põline mets. Haavad olid nii jämedad, et kahekesi said ümbert kinni võtta. Kõrval oli Tuprova küla, kõige enne tuli üks Laasbergi 
Juhan sinna oma perega. Seal oli nii kõrge burjan ${ }^{6}$ - puuvõsud ja mis kõik seal kasvas. Juhan ütles vanamoorile, et sina ole hobusega siin, aga ma vaadan, kas kuskil on lagedamat kohta. Ja kaotas vanamoori kõige hobusega sinna rohu sisse. Pärast hakkas karjuma ja sai nii vanamoori kätte. (Tallinn < Uljanovski obl, Smorodino k < naine, snd 1954 (2009))

Metsiku paiga kujundit võimendavad lood, milles jutustatakse kokkupuudetest uues elupaigas inimesele kardetavate ja ka kariloomadele ohtlike metsloomadega (hundid, karud).

Karud olid seal suured, nagu normaalne keskmine hobune. Kui karu ründama hakkab, tõuseb kahe käpa peale püsti. Üks juhus oli: Minu mehe isa läks hobust tooma, seal nimetati karjamaad paskodinaks ${ }^{7}$. Külal oli aed ümberringi ja küla taga metsa ääres olid nisukesed heinalapid. Karu tõusis kahe käpa peale püsti, ei olnud poegigi. Äi sai õnneks puu otsa ronida, tükk aega istus puu otsas, karu vahtis teda ja siis hakkas astuma. (Lääne-Virumaa, Avispea k < Tomski obl, Liliengofi k < naine, snd 1935 (2009))

Venemaa eestlaste metsloomalugudes võib leida kokkupuutepunkte usundilise maailmaga, näiteks:

Minu isale, kui ta Koltsovos koolis käis, olevat hunt vastu tulnud. Visanud käpa õla peale ja löönud keelega üle näo: tal oli suu nagu kinni kasvanud, ja läks edasi. Räägitakse, et hunt ei saa midagi teha, kui ta kuu all magab.

(Tartumaa, Elva l < Kemerovo obl, Koltsovo k < naine, snd 1937 (2003))

Analoogilisi uskumusteateid, et hunt ei saa teatud ajal või põhjusel lõugu lahti teha, leidub Eesti Rahvaluule Arhiivis (vt nt ERA II 178, 251 (8) < Kuusalu khk ja v, Kõnnu k; ERA II 138, 88 (58) < Häädemeeste khk, Orajõe v, Kabli k (1937)).

Huntidega seotud uskumustest on märgatav osa seotud loomade karjatamisega, sest just kariloomadele olid nad eriti ohtlikud. Näiteks on usutud, et huntide valitseja või püha Jüri keerab jüripäeva ajal hundi suu lukku ja päästvat selle lukust valla alles mihklipäeval. Sel ajavahemikul ei olevat tohtinud hundid karja murda (Kõiva 2011: 48).

Oma karjapõlvest rääkides meenutab üks jutustaja oma vanaema, kes kasutanud huntide peletamiseks vanast traditsioonist pärit maagilist tõrjevormelit.

Teinekord olid hundid kohe seal küla lähedal, siis mina karjas ei olnud, aga mu õde vist oli. Jooksis külasse, et: "Hunt, hunt!” No siis läksid naised. Vanaema Katril ikka oli rohtu iga asja vastu. Siis karjusid kõik kooris: “Tõ-hu, tõ-hu!” Ma ei tea, mis see siis pidi olema. Aga seekord hunt vist võttis üheainsa lamba, sellega läks ära ja teised jäid alles. (Võrumaa, Väimela v < Kirovi obl, Oparino raj < naine, snd 1933 (2005)) 
Eesti loitse uurinud Mare Kõiva täheldab, et hundisõnad kuulunud vanasti karjaste oskuste arsenali (Kõiva 2011: 49-53).

Esivanemate elukohaks saanud tühja asustamata paiga kujutluse kõrval kohtab perelugudes ka jutte, mis kajastavad konflikte piirkonna varasemate elanikega. Neis võib leida puutepunkte ja liitumisi rahvapärimuses tuntud jõumehe-juttude ja hiiumuistenditega. Hiiumuistenditele on omane füüsilise jõu imetlemine, kusjuures inimese fantaasia paisutab jõu ja suuruse mõõtmed kaugelt üle võimalikkuse piiride (vt Laugaste \& Liiv \& Normann 1963: 23).

Vanaema rääkis, et nendele oli määratud seemnevilja saamine kuskil Jontali külast, vene külast venelaste käest pidi seemnevilja saama. Nojaa eestlased läksid Jontali külla hobustega, aga venelased olid neid kaigastega vastu võtnud. Ja oli kõvaks löömaks läinud. Minu vanaisa olnud tagapool rohkem, tema oli selline tasane ja vist arg vennikene ka, keeranud hobuse ringi ja pannud sealt ajama, tal olnud hästi väle hobune. Aga üks mees Oja Vidrik, suur mees olnud ja palju jõudu, rakendanud hobuse lahti ja võtnud ree aisa välja. Aga venelased sealkandis olid väikesekasvulised. Hakanud selle aisaga keerutama, siis olnud kõik venelased laiali. No aga vilja nad muidugi ei saanud. (Võrumaa, Väimela v < Kirovi obl, Oparino raj < naine, snd 1933 (2005))

Võrdlusena võib välja tuua, et ka Saaremaa hiiu Suure Tõllu lugudes kohtab sõdimist vaenlastega vankri või reheparre abil (vt Laugaste \& Liiv \& Normann 1963: 35, 236-239).

Teisele analoogilist konflikti kajastavale loole liitub Eesti traditsioonis üldtuntud suure viljakotiga veskil käimise lugu.

Krasnõi Jari venelastega olevat vanal ajal kõvasti lahinguid löödud. Jansoni Juhan oli kõva poiss, terve tänava venelased tulnud talle kallale. Tema saanud aia otsast kätte hobuse pealuu. Kui tolle luuga löönud, olnud kõigil venelastel jalad püsti.

Ja Jansoni Juhan läinud veskile, võtnud madratsikoti, nii suur kott olnud nagu vanker. Küsinud venelastelt, et adin mešokk, prapustiite . $^{\text {. }}$ Üksainuke kotike, et laske läbi, ma ei hakka seda suurt järjekorda ära ootama. Venelased ütelnud, et horošoo ${ }^{9}$. Teise korra peale oli vaja kott üles viia, Juhan hiivanud tolle koti vankri pealt püsti, venelased löönud risti ette. Appi ka ei läinud. Juhan võtnud koti turjale ja läinud. (Tartu 1 < Kemerovo obl, Koltsovo k < mees, snd 1928 (2009))

Eesti traditsiooni kohta vt nt ERA II 226, 602/3 (9) < Risti khk, Nõva v, Hindaste k < Kullamaa, Kolovere v (1939); ERA II 272, 407/8 (1) Haljala khk, Vihula v (1940). Vrd Tugeva Matsi lugu (ATU 650A). 
Kohanemiselood kajastavad elu sisseseadmise raskusi võorsil - kokkupuuteid metsiku looduse ja varasemate asukatega ning püüdlusi selle kõigega toime tulla ja ennast kehtestada. Esivanematelt päritud maagilisi toiminguid võib käsitleda kui enesekaitset. Vanast kodupaigast kaasa võetud kohanimed aitavad uusasukatel territooriumi kinnistada ja omaseks muuta.

\section{Ajaloosündmuste kajastused perelugudes}

Pöördeliste ajaloosündmuste kajastused on leidnud oma koha ka Venemaa eesti kogukondades sündinud-kasvanud eestlaste perelugudes. Ajaloosündmustest jutustamist võib mõista kui rahvapärast ajalootõlgendust, kus jutustaja tõlgendab nii iseenda läbielatud sündmusi kui ka lähikondlastelt kuuldut nii-öelda oma ajaloona, mõtestades minevikku ja andes tähenduse jutustamisajale (Jaago 2003b: 191). Pärimusliku ajaloo ehk suulise ajaloo läbimurre algas folkloristikas 1990. aastatel, kui uurijad hakkasid täpsemalt tähele panema pärimusmaterjali tekkeviise ja kontekste ning seda, mida, kuidas ja kellele inimesed jutustavad oma minevikust ning kuidas nad ise jutustusi tõlgendavad (Peltonen 2003: 179).

Venemaa kodusõjast ${ }^{10}$ jutustavad lood on tuntud ootuspäraselt nendes Siberi piirkondades, kus esivanemate elupaigad jäid otsese lahingutegevuse alla.

Kodusõja ajast räägiti, et kasakad tulid, panid külasid põlema. Külarahvas teadis, et kasakad tulevad meie külasse ka. Inimesed läksid külast välja, kuhu keegi sai peitu või pakku. Nad olid juba mitu päeva ära olnud. Vanaisa oli ütelnud, et peab minema ikka koju käima, et loomad on söömata. See oli novembrikuus, mina sain siis just aastaseks. Isa tuli külasse ja seal hakati noori mehi taga otsima, need hakkasid kasakatele vastu. Nojaa isa lasti maha. Keda koduõuest ja kuskilt kätte saadi, tapeti kõik mehed. Seal olid kohe olnud kuskilt taraaias tapetud inimesed, terved pikad read. [---] Minu tädi oli ka külas, ta ei läinud peitu. Kartsid, et kasakad hakkavad pooma, keda kätte saavad. Üks mees oli teinud kõigile poomispaelad, kuus paela tegi valmis, et poome iseendid ära, muidu homme puuakse meid. Seal olid tema tütred ja naine ja tema ise ja meie Liisa. Aga vana naine hakkas vastu, ütles, et tulgu ja poogu, aga tema ennast ise pooma ei hakka. Aga järgmisel päeval oli rahu. (Tallinn < Krasnojarski krai, Ülem-Suetuki k < naine, snd 1917 (2009))

Loos on esil sõda - hirm ja sellega seotud vägivald - isa jt külameeste tapmine, samas ka püüd vägivallale vastu seista ja sellega toime tulla. Ulla-Maija Peltonen on Soome kodusõja näitel uurinud, kuidas inimesed jutustades ja vaikides ühiskondlikule vägivallale reageerivad, seda tõlgendavad ja sellest lõpuks välja tulevad (Peltonen 2003: 179). 
Neis ajaloosündmusi kajastavates juttudes kerkivad teemana esile ka valgete ja punaste rüüsteretked talumajapidamistesse.

Vanaema rääkis, et isakodus oli nendel saun ja sellel suveköök või nisuke eesruum. Ja parajasti vahetati neid pliidikive, mis olid ära põlenud. Saviküna ühes otsas oli savi tehtud seal. Ja valged tulid. Aga vanaisal oli olnud vana ja uus tulup, suur kasukas, pikk, millega käidi pikal teel, ja uued vildid. Vanaisa võtnud selle küna, puistanud savi kõrvale hunnikusse ja keeranud vildid ja tulupi lina sisse, pannud küna alla, keeranud küna kummuli. Sõdurid tulnud ukse peale, vaadanud ringi, et "nitševoo netu"11 ja läinud ukse pealt tagasi. Aga tagapool oli saun suitsuliha täis, oli juba ära suitsetatud ja kuivas seal. Pärast olid tulnud punased-keegi oli juba valvel ja teatas ette, et tulevad. Siis kasteti tekid märjaks ja pandi need akna ette. Lõikasid sauna postid maha ja lasid katuse alla ukse ette. Siis tasandasid lumega kõik ära. Punased tulnud juurde: "Siin on katuski sisse kukkunud, saunas ei saa kedagi olla.” Saunatäis liha jäi alles. (Ida-Virumaa, Kohtla-Järve $1<$ Novosibirski obl, Vlaskina $\mathrm{k}$ $<$ naine, snd 1929 (2009))

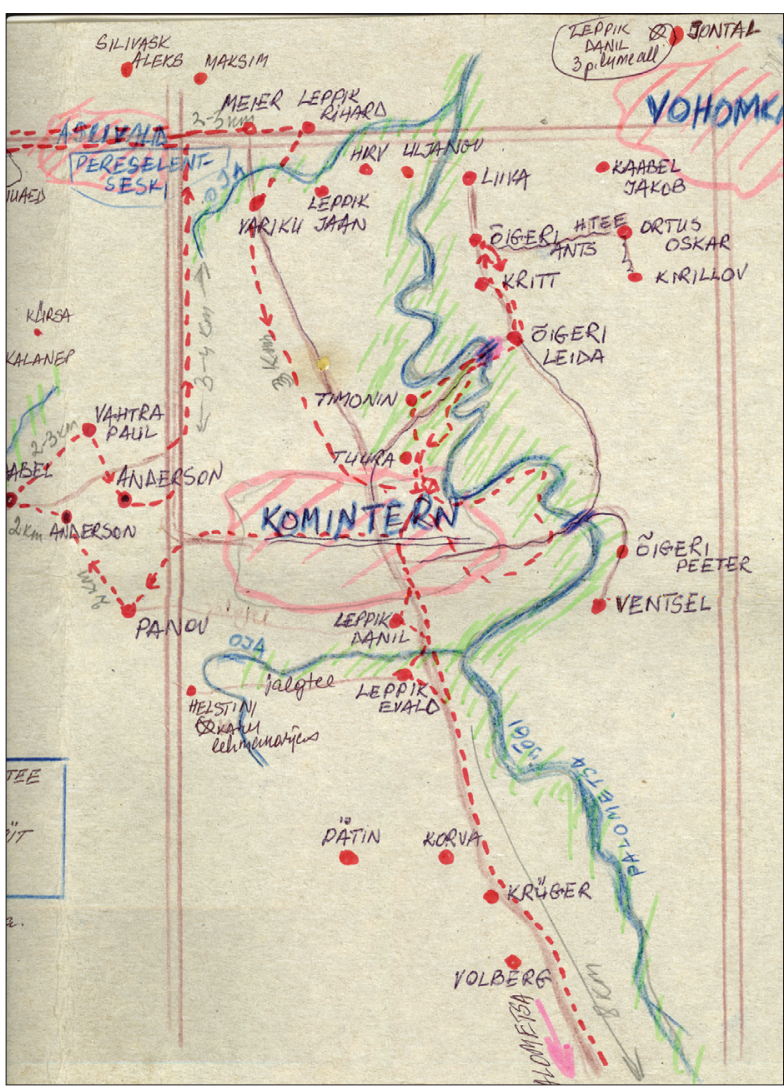

Loos põimuvad argielu ja sõjasündmused. Keskendutakse pereliikme leidlikkusele, mis päästab kodakondsed näljahädast.
Foto 8. Eestlaste kunagised elupaigad Vjatkamaal Oparino rajoonis. Kominterni küla plaan, mis valmis 1983. aasta suvel külaskäigul lapsepõlvemaile.

Kaart on saadud Ella Pohlalt. 
Kui jutustatakse Teisest maailmasõjast, on perelugude keskmes veelgi enam viletsus ja näljahäda külades. Paljud Venemaa külad, kust jutustajad pärit olid, jäid Teise maailmasõja päevil otsesest lahingutegevusest kõrvale. Samas olid mehed sõjas, naised-lapsed pidid majapidamistega ise hakkama saama, külades valitses toidupuudus. Perelugudes on kesksel kohal viletsates oludes toimetulek.

Süüa oli niivõrd vähe ja laste tähelepanu oli ilmselt vaja kuskile toidust eemale juhtida. Siis oli "Ridaemanda sauna viimise mäng”. See oli lastele hirmus lõbus. Muud ei tahetud, kui ikka "Ridaemandat" mängida. [Järgneb üksikasjalik mängu seletus.] (Võrumaa, Väimela v < Kirovi obl, Oparino raj < naine, snd 1933 (2005))

Sarnane mäng, nimetusega "Ridakitkumine," on tuntud ka Eestimaa traditsioonis, vt nt ERA II 102, 341/3 (17) < Rõuge khk, Nursi v (1935) ${ }^{12}$. Kuid jutus tõstetakse esile vanaema leidlikkust laste tähelepanu toidult eemale juhtimisel.

Soome kodusõja-aegseid mälestusi uurinud Ulla-Maija Peltonen (2003: 184) on välja toonud asjaolu, et kodusõjajärgsel ajal käisid soomlased massiliselt spiritistlikel seanssidel, et välja selgitada lähedaste saatusi. Esimese maailmasõja järgset aega on nimetatud spiritismi õitsenguajaks, kuna inimesed vajasid abi (Winter 1997: 54-57). Ennustamisega seotud uskumused lähtuvad eeldusest, et tulevik on mingil kujul juba ette määratud ja selle kohta on teatud eriliste annetega isikutel, aga mingis ulatuses ka igal tavainimesel võimalik teavet saada. Püüe suuri katastroofe nagu sõjad ja taudid ette ennustada on olnud üsna üldine (Hiiemäe 2013: 11, 174-175). Teise maailmasõja ajal ja järel oli ka Venemaal sündinud eestlaste seas tavapärane, et sõjas viibivate lähedaste kohta püüti teateid hankida ja sõja lõppu ennustada.

Sõja lõppu oodati ja seda ikka igal viisil prooviti ette näha, kas sõda ikka lõpeb või ei lõpe. See oli üks vene naise jutt, et peab polenitsa, see oli selline suur pikk puuhalg, pidi selle polenitsaga minema koputama kuskile talli juurde. Ja siis pidid kuulatama niimoodi, kas hobused krõmpsutavad heina, kas söövad rahulikult või jäävad vait. Kui hobune krõmpsutas, siis pidi sõda jätkuma. Aga kui hobune jäi kuulatama, siis pidi sõda ära lõppema. Aga minu meelest, tookord, kui me käisime, et siis küll sõda veel ei lõppenud. (Võrumaa, Väimela v < Kirovo obl, Oparino raj < naine, snd 1933 (2005))

Koputamise järgi surma vms ennustamine on tuntud ka Eesti traditsioonis. Venemaa külades elasid eestlased lähestikku venelaste jt ümberkaudsete rahvastega ning mõistagi kasutati ka naabritelt õpitut. 
Teise maailmasõjaga seoses jutustab mees, kes teismelise poisina käis Tomski turul liha müümas, seal osavalt tegutsenud vargapoistest.

Sõjaaeg, kui isa oli sõjas, käisin mina [turul] mü̈̈mas. Siis mul oli tädimees kuskil üks 70-aastane, tema käis ka Tomski turul. Olid niisugused pikad letid. Panid looma sinna, raiusid ta katki, näitasid tükke ja müüsid. Temal oli kaunis tühi kohver käes, raha oli võtnud taskust välja, visanud sinna kohvrisse. Omatehtud kohvrid olid, niisugused vineerist või õhukestest laudadest. Ja poisid ründasid teda. Õieti üks poiss hüppas talle juurde, et djadja spasti ${ }^{13}$, et no onu aita. Ja siis teised viis-kuus tükki tulid, kaikad käes, justkui sellele poisile kallale. Ja tema tahtis poissi aidata, tõrjus neid eemale ja sel ajal võeti rahaga kohver ära. Nisukesi vargaid oli Tomski linnas palju. (Tallinn < Tomski obl, Liliengofi $\mathrm{k}<$ mees, snd 1929 (2005))

Vargusi ja röövimisi tuli neil rasketel aegadel sageli ette. Eestis seostatakse sõjajärgsel perioodil vargustega sageli rahvasuus kotipoiste nime saanud tulnukaid, kes jõudsid siia pärast 1946. aastal kaotatud raudtee sõidulubade süsteemi. Neid pani liikuma toidupuudus või lausa nälg (1946-1947 oli näljahäda Moldaavias, Ukrainas ja Venemaal). Nad kerjasid või varastasid toiduaineid, ajuti ka röövlitööd ette võttes (Noormets 2015: 74).

Sugulase sõjajärgselt linna elama minekust jutustamine - inimeste külast lahkumine oli seotud suurte raskustega, sest kolhoosid ei tahtnud tööjõust ilma jääda - toob esile folklooris tuntud linnalegendi - küüned süldis. Need jutud levisid massiliselt Teise maailmasõja-järgsel perioodil, ka Siberi eestlaste seas.

Ei tahtnud ju teha seda kolhoositööd, raske oli, aga kolhoosist eriti ära ei lastud. Meil ei olnud ju dokumente. Näiteks õde Helmi läks pärast selle õe juurde, kes elas Mariinskis. Tema pidi valetama oma sünniaasta. Ta oli tehtud oma kümme aastat nooremaks, et nagu oleks saanud alles 16, siis sai kuidagi passi. Aga üldiselt anti ainult mingisugune tõend, passe ei olnud. Olime nagu vangid! Linna töö oli ikka kergem. Mariinski linnas oli küll suur vangla. Paljud kinnipeetud, kui said vanglast lahti, jäid Mariinskisse elama. Ja noid pätte ikka oli. Linna pargis oli keegi maha löödud, kiviga kohe pähe löödud. Kuritegevust jätkus Mariinski linnas küll omajagu. Räägiti, et sõja ajal oli Mariinskis terve vabrik avatud, et vorsti seest oli inimese küüned leitud ja mis seal veel oli. Ja ma usun, et võib-olla tõesti nii võis olla, sest nii suur nälg oli. (Tartumaa, Elva 1 < Kemerovo obl, Jurjevi k < naine, snd 1937 (2005)) 
On arvatud, et inimesed, kes räägivad muistendeid, verbaliseerivad oma hirme ja vabastavad end nii sellest. Tänapäeva muistendeid uurinud Eda Kalmre möönab, et vorstivabriku lugu on ühelt põlvelt teisele edasi antud kui ajaloolist tunnistust nõukogude aja koledustest. Lugude funktsioon on selles, et nad lubavad jutustajatel välja öelda oma arvamuse nii personaalselt kui ka ühiselt elatud ajaloo kohta. Vorstivabriku lugu on üks sõjajärgse ajastu uskumusi, eelarvamusi, väärtushinnanguid ja stereotüüpe sisaldavaid tunnusjutte, millele on iseloomulik mitmekülgne ja tähenduslik potentsiaal. Kuulujutust on saanud ajaloost rääkimise viis (Kalmre 2008: 165, 189).

\section{Eluringi tähtsündmused}

Oma perest jutustamisel kerkivad mõistagi esile eluringiga (sünd, ristsed, katsikud, pulmad, matused) seotud kombed, uskumused ja ended. Pärimuslikus kogukonnas saatsid olulisemaid üleminekuaegu kaitsemaagilised rituaalid, õigest või valest käitumisest arvati sõltuvat inimese/inimeste edasine käekäik.

Lapse sünniga seoses meenutavad Venemaal sündinud-kasvanud eestlased sageli omaenda esimest sünnitust või oma noorema õe või venna sünniga seonduvat.

Kui minu noorem õde sündis, ma olin siis kuue-aastane. Ma ei teadnud laste sündimisest mitte midagi. Saadeti onunaise poole, üteldi, et onunaisel on mett ja nendel on ikka leiba ja, saadeti mind karja sinna. Ma olin suvi läbi karjas, metsa sees. Õde sündis septembris, siis onunaine ütles, et lähme nü̈̈d teie poole külla, tegi pannkooki ja keetis kompotti. Ütles, et teile on kurg väikse lapse toonud. Mina seal ümberringi lapsi teadsin, mõtlesin, kas ta tõi Jansoni lapse ära või tõi Tihase lapse või Saksa lapse. Läksime sisse, vaatasin voodisse ja ütlesin: “Oh, minu teki sisse veel pugenud!" Siis vaatasin, et päris väikene, et see on ikka kure toodud, et külas ei olegi nisukesi. Minul on siin kukla taga punane märk, üteldi, et kurg tõi sind. Kui ema mind kandis, oli korsten läinud põlema ja ema ehmatas ja lõi käed kuidagi kukla taha. Ta teadis, et kui ehmatad, ei tohi nägu katsuda. (Tartu l < Kemerovo obl, Koltsovo k < naine, snd 1929 (2009))

Kuna Siberi külades sünnitati vähemalt 1950. aastateni kodus, lapsi püüti hoida sünnituse asjus teadmatuses, oli kombeks selleks ajaks lapsed kodunt eemale toimetada. Lapse sünni kohta oli levinuim seletus lapsele, et kurg tõi, mis on eesti traditsiooni jõudnud saksa eeskujude järgi (Kõivupuu 2015: 29). Väga levinud on ka lapse sünnimärgi nn tulekahjumärgi seletamine ema nähtud tulekahjuga ja sellest tuleneva ehmatusega lapse kandmise ajal. 
Oma esimesest sünnitusest meenutab teine naine:

Tüdrukuga ma jäin reedel haigeks, pühapäeval ta alles sündis. Oma ema ja Jaani sugulane ja onunaine olid seal juures. Mul on meeles, käed koos kõik palusime. Mul juuksed võeti lahti, ma ei tea, mispärast nood juuksed pidi lahti võtma. Kunagi enne, kui minu ema sünnitas, oli külas üks ämmaemand Tiidebergi Kata, meile oli ta sugulane, see võttis kõik lapsed vastu. (Tallinn < Kemerovo obl, Jurjevi k < naine, snd 1924 (2009))

Viimases loos mäletab jutustaja, et ta juuksed põimiti lahti, kuid ei tunne kombe usundilist tagapõhja. Vana uskumuse kohaselt pidi sünnitajal sünnituse kergendamiseks kõik sõlmed lahti päästma. Sünnituse ajal ja järel viidi läbi ka mitmesuguseid maagilisi toiminguid, millega taotleti vastsündinule õnne (Kõivupuu 2015: 24).

Vastsündinu külastamine kuulub nii meie kui teistegi Euroopa rahvaste peretraditsioonide hulka. Traditsiooniliselt ei mindud katsikule tühja käega (vt Kõivupuu 2015: 37, 43-45). Nii teavad ka Venemaa eesti kogukondadest pärit eestlased, et nurganaist vaatama minnes, ka elades kitsastes oludes, peab midagi kaasa viima.

Kui laps sündis, siis oli ikka midagi valmistatud, miski nisukest õhukest, ei tohtinudki uuest riidest olla: hakkab palju riideid pidama. No enamasti meeste seljatagustest sai midagi teha. [---] Meil öeldi nurganaine. Ikka midagi söögikraami toodi talle, kalatsid ${ }^{14}$ küpsetati. Arvati, et nurganaist vaja vaika ${ }^{15}$ kiviga visata, aga peab minema vaatama. Ja kuus nädalat pidi naine kodus olema, ei tohtinud välja tulla. Ja kuus nädalat pidi olema laps peidus, et sul keegi ei näegi teda. Kui olid kirikus ära käinud, siis võisid lapsega minna igale poole. Ta [vastsündinu ema] ei käinudki enne kirikus ka, kui oli kuus nädalat möödas. (Tallinn < Krasnojarski krai, Ülem-Suetuki k < naine, snd 1917 (2009))

Ka usuti, et kuri silm võib kahjustada nii väikelast kui ka ema ning püüti hoolikalt jälgida nõuet, et väikelapse ema püsib koos lapsega teatud aja pärast sünnitust kodus.

Pulmi, mis on talupojakultuuris olnud suguvõsade keskne rohkete rituaalidega üritus, peeti Teise maailmasõja ajal ja sellele järgnenud majanduslikult kehvadel aastatel harva. Mõnes Venemaal sündinud eestlase loos tuleb esile vanemate osa laste paaripanemisel. Üks naine jutustas, kuidas ta pandi 17aastasena mehele noormehele, keda ta eelnevalt ei tundnud, et kogu pere saaks ümber asuda majanduslikult paremal järjel olevasse külla (vt Korb 2010: 139). Kuna ta ei olnud varem pulmas käinud, oli kogu seal toimuv talle uudne. 


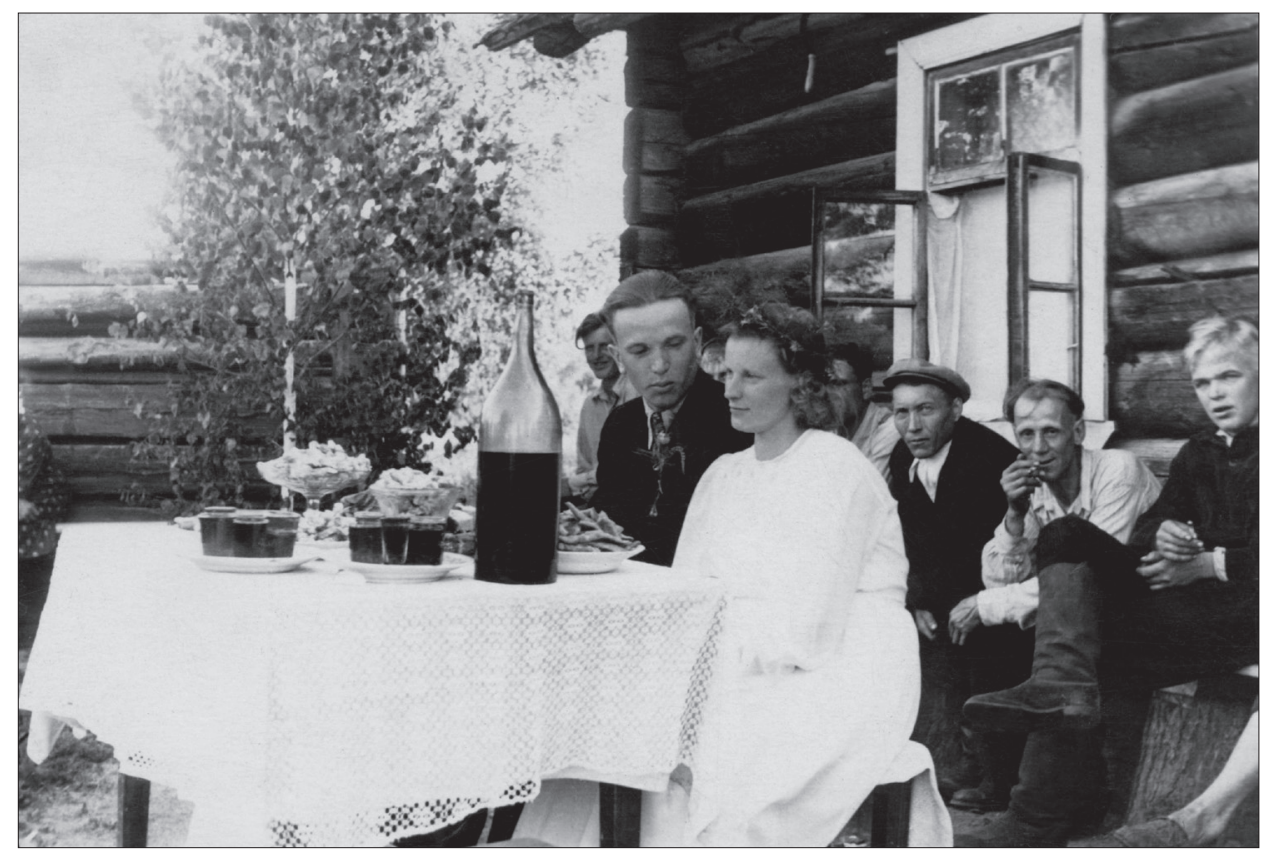

Foto 9. Noorpaar Elmi ja Eindri Kurg oma pulmapäeval 7.07. 1957. aastal. Tomski oblast, Liliengofi küla. Foto eraarhiivist.

Meose pere oli heal järjel ning pulmadeks muretseti mulle imeilus valge siidkleit ning pulmakraam osteti Tomski linnast. Laual oli riigiviin. Pulma oli kutsutud umbes 40 inimest, kogu Kaseküla koorekiht, sest peiu ema Julie oli väga populaarne. Need olid tolle aja kohta suured pulmad. Siis üldiselt pulmi ei peetud, tavaliselt käidi kahekesi külanõukogus registreerimas. Ma polnud enne pulmi näinud, ja kui meie pulmas suleti tee palkidega, arvasin mina, et sõideti kogemata vastu maja seina. Kui isamees tuli viinapudeliga, oli tee jälle lahti. Pulmas asetati meie ette lauale raha ning sellest vaadati, kumb peale jääb - "pruudi jalg või peigmehe jalg?" Loomulikult jäi peigmehe oma peale. Raha koguti pulmas koguni nii palju, et pulmaviin sai tasa. (Võrumaa, Räpina < Tomski obl, Kaseküla < naine, snd 1923 (2004))

Samast piirkonnast pärit mees abiellus 1958. aastal venelannaga, kes oli eesti külla saadetud velsker-ämmaemandaks. Moskvast pärit pruudi sugulased pulma tulla ei saanud ja nii peeti pulmapidu mehe kodus ja eesti kombeid järgides. 
Kui ma pruudi järele läksin, olid tüdrukud maskeeritud. Kooliõpetajad ja Juulia sõbrannad istusid kuuekesi pika pingi peal, rätikud või linad üle. Katsuda ei tohtinud, pidid oma üles leidma. Me olime enne Juuliaga kokku leppinud, kui hakkan valima, ta liigutab jalga. Üks kooliõpetaja liigutas ka jalgu. Karvudi Jaan oli isamees, see muidugi teadis. Isamehega me läksime Kasekülla pruudile järele, pulmarahvas oli kõik Liliengofis. Kaseküla külanõukogus registreerisime ära. [---] Edasi sõitsime Liliengofi. Täkk oli ehitud, kellad lookas ja hobuse riistad olid kilpidega. Täkk oli saani ees nisukene maru, sõitis nii, et porine tee taga. Liliengofis võeti meid värava juures vastu. Kus peeti kinni, sinna tuli pudel anda, väljaostmine oli samaka ja viinaga. [---] Toidud keetis ema. Mamma üksinda muidugi ei jõudnud, naabrid olid abiks. Tehti oma vorst, süldid, leivad ja saiakesed ja... Kõik ei mahtunud korraga lauda. Toas ümberringi olid lauad, seal sai ainult istuda ja sü̈̈a. Suur laudadest põrand oli tehtud, päeval oli juba soe, tantsiti väljas. Ühed tantsisid, teised istusid lauas. Nojaa seal peideti pruuti ja varastati pruuti. Mul oli kinomootor, millega valgus pandi tuppa ja poisid jätsid mootori seisma, tuli kustus. Pidin jooksma seda käima panema, selle aja sees varastati pruut ära. Ikka omad poisid seal tegid tükke. Nojaa pruut oli peidetud aita, sain ikka kätte. (LääneVirumaa, Väike-Maarja < Tomski obl, Kaseküla < Liliengofi k < mees, snd 1935 (2009))

Kirjeldusest leiame vanadest pulmakommetest pärit rituaale nagu tee sulgemine, rahakogumine, pruudi maskeerimine, pulmahobu ehtimine, pruudi varastamine jm, mis kõik on tuntud ka Eestimaa pulmades. (Eesti pulmakommete kohta vt Tedre 1973, Õunapuu 2003.) Vastastikune abistamine kogukonnas on tuntud olnud nii pulmade kui ka matuste korral (vt nt Torp-Kõivupuu 2003: 73). Võrreldes teiste peretraditsioonidega on matusekombestik olemuselt suhteliselt konservatiivsem ning püsivam. Oma kogemusele tuginedes ja segaabielude sagenedes kirjeldatakse kogukonna matusekombeid, eesti ja vene matuste erinevusi: eestlased kutsuvad matustele, venelased tulevad ise; eestlastele on iseloomulik vastastikune abistamine matustel; eestlaste matuselaual on nii lusikad kui ka kahvlid, venelastel ainult lusikad jm. (Siberi eestlaste matusekommete kohta vt lähemalt Korb 2003b: 103-142.)

Omakse surmast ja matustest rääkides võivad mälestustes esile kerkida ka hoopis muud teemad, näiteks jutt peidetud varandusest, milles varanduse oletatav asukoht jääb konkretiseerimata.

Räägitakse, et Jaagupil olnud tšetvernoi täis kulda. Kui ta tundis, et hakkab surema, läinud ta välja, pannud selle noi ühe puhvaika või mille sisse, matnud kulla maha, ei jätnud perele. See kuld on vist praegugi kuskil 


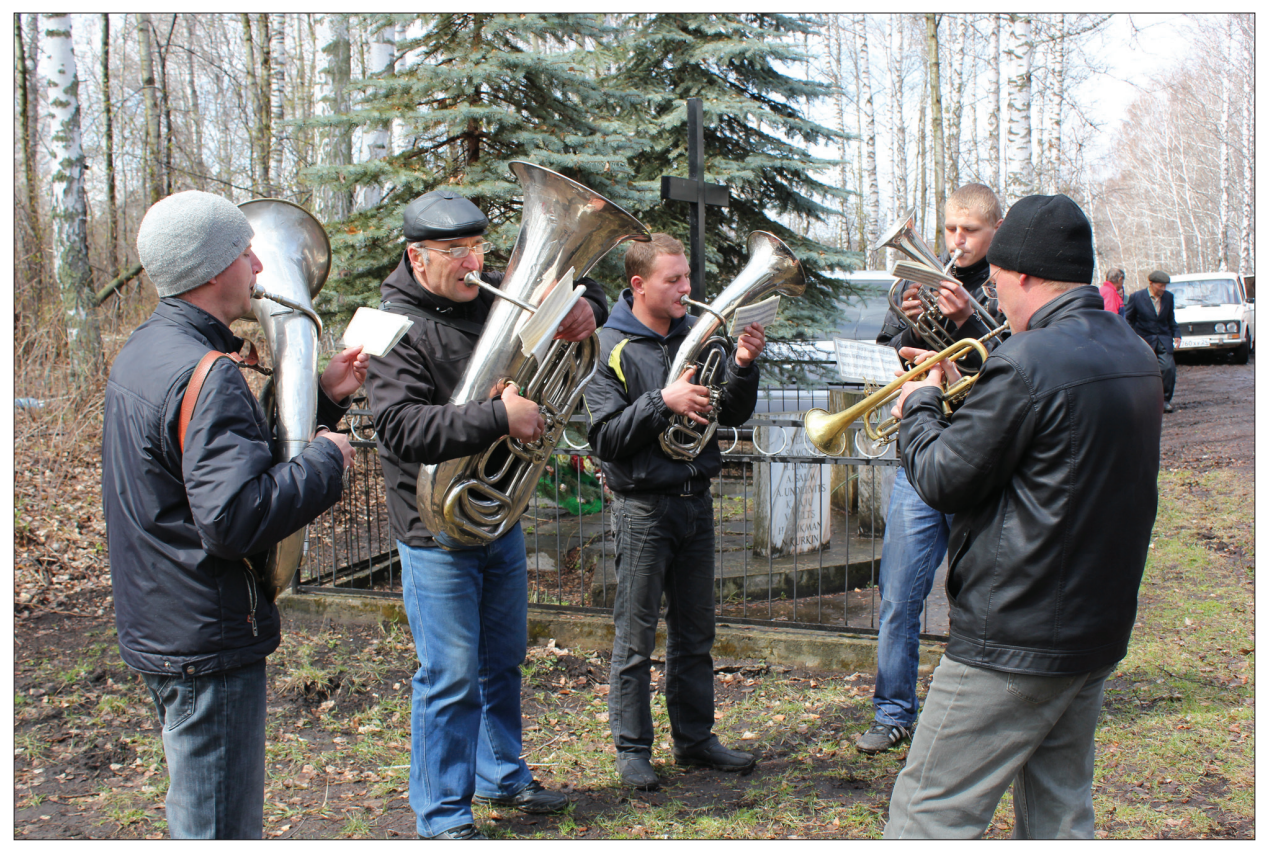

Foto 10. Ülem-Suetuki puhkpilliorkester Villa Manni matustel. Andreas Kalkuni foto 2012.

Siberi maa sees, terve noi täis kulda. Nad elasid Kasekülas luha kaldal. (Võrumaa, Räpina < Tomski obl, Kaseküla < naine, snd 1923 (2004))

Eesti aardejutte uurinud ja liigitanud Mare Kalda tõdeb, et teatud jututüüpe esindavad tekstid ei paiguta jutusisu kohapärimuslikku seosesse ning toob näitena esile levikult silmapaistva juturühma "Kelle käsi paneb, selle käsi võtab" (eesti P 536, soome P 421) (Kalda 2014: 270).

Teine jutustaja räägib oma ema surmast, tuues samaaegselt esile talle teadaolevad rahvapärased roosi arstimise viisid.

Kui hakati ema pesema, leidsid, et talle oli ehmatusest roos rinda löönud, roos lämmatas ta ära. Aga roosi rohtu teadis külas igaüks ja ma tean seda ka. Selleks hoiti naiste pahade päevade kuiva lappi. Seda peab kolme päeva jooksul kuivalt mässima haige koha peale, haige koht ei tohi külma ega märga saada. Ja kaalikalehtedest, talvisel ajal kaalikapudrust on ka roosi puhul abi. Ja kolmas ravivahend on naturaaltubakas, ennem kasvatati ise tubakat. Pandi peale toore tubaka lehed suvisel ajal; talvel tubakas, mesi ja sibul segi tambituna. (Ida-Virumaa, Kohtla-Järve 1 < Novosibirski obl, Vlaskina k < naine, snd 1929 (2009)) 


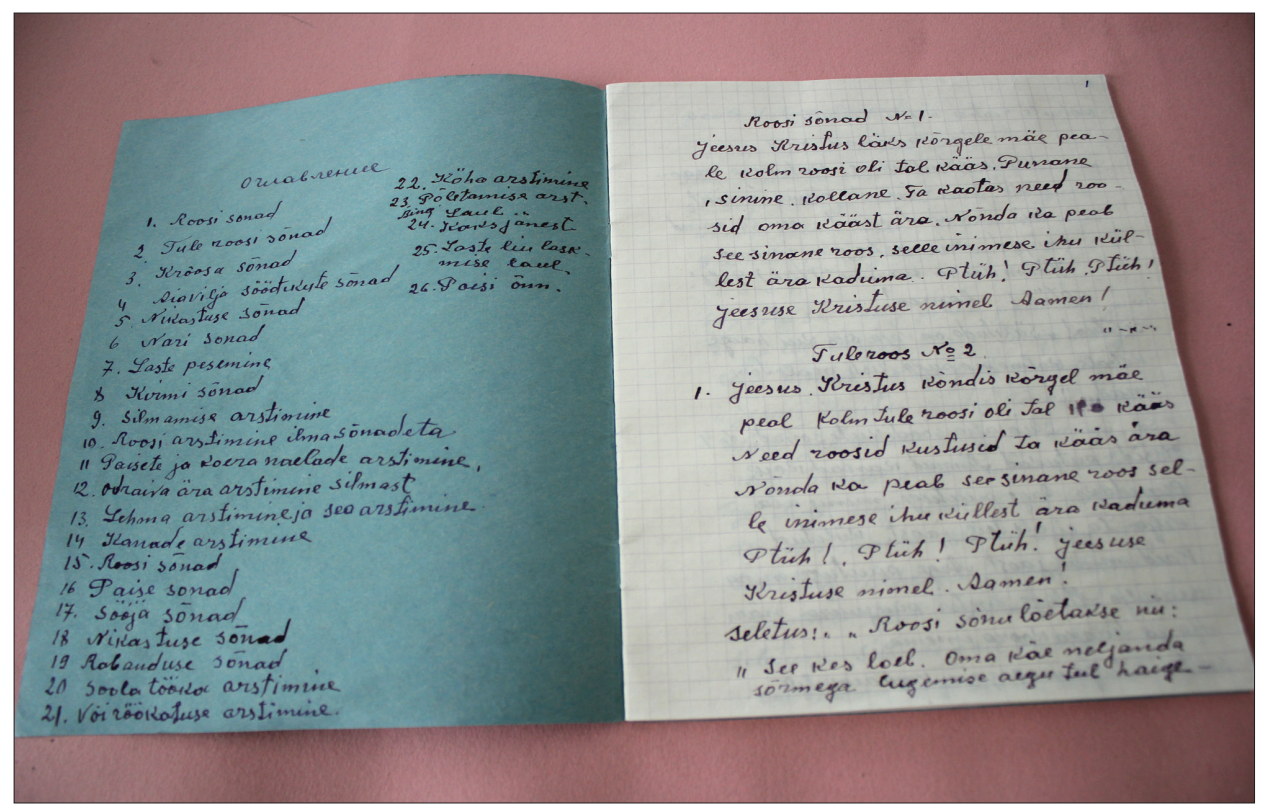

Foto 11. Ottessoni Roosi 1974. a kirja pandud roosisõnad Minussinski koduloomuuseumis. Anu Korbi foto 2013. ERA, DK 87.

Roos (vanem nimetus eliting, ka pahus) tähistas põletikulisi suurte valudega haigusi roosist luutuberkuloosi ja keskkõrvapõletikuni. See arvati tekkivat ehmatusest või mõnest afektiivsest seisundist, ka külmetamisest. Arvati olevat üheksa liiki roosi, eri vorme eristati värvi, päritolu ja haiguskoha järgi (Kõiva 2011: 233; arstimisõnade ja viiside kohta vt Kõiva 2011: 233-242).

Eluringi mälestusi jagades räägitakse iseenda ja oma pere lugusid, kuid jutustajad toetuvad suuresti kogukondlikule teadmisele. Venemaa eestlaste külakogukonna kombetalitused on vanemate inimeste sotsiaalse kontrolli all: väljakujunenud tavade eiramist pannakse pahaks ja turvalisem tundub teha nii, nagu enne tehtud. Nii mäletatakse vanu tavasid suhteliselt hästi, kuid nende usundilise tagapõhja tundmine on hääbumas.

\section{Kokkuvõtteks}

Elulooliste mälestuste loomises on seotud nii jutustatava sündmuse aeg, jutustamise aeg kui ka sinna vahele jääv aegruum oma muutumises, kultuurimälu vahendusel toimib minevikukogemuse ülekandmine olevikule. Venemaa eesti 
kogukondades sündinud-kasvanud inimeste lugusid analüüsides tuleb arvesse võtta asjaolu, et nad olid mitukümmend aastat varem lahkunud oma sünnikohast ja rajanud uue kodu Eestis. Kuna nad on säilitanud sidemed oma kodukülaga Venemaal ja/või sealt pärit inimestega Eestis, on neil olnud võimalus oma isiklikke mälestusi ka hiljem nendega jagada. Kogemus on individuaalne, aga oma kogemusi jagatakse teistega sellest jutustamise abil. Nii vahendatakse lugudes omaenda kogemuse kõrval ka oma pere ja kogukonna kogemust. Samas on Venemaalt Eestisse elama asunud eestlaste pere- ja sünniküla ajaloo tundmine võrreldes Venemaal kohapeal elavate eestlastega nõrgenenud, sest neil pole enam oma päritolupaikadega otsest seost.

Kogukondliku elu juures põimub pärimuskeskkond tihedalt eluloolise keskkonnaga. Kogutud mälestused sisaldavad ehtsaid rahvajutte, rahvapäraseid ajalootõlgendusi, loitse, kombestikukirjeldusi, uskumusteateid vms. Põlvest põlve edasi antud teadmised, kogemused, kombed, ka kuuldud lood mõjutavad suuresti inimest ning leiavad oma koha ka eluloolistes mälestustes. Jutustuse kaudu mõjutatakse lokaalset traditsiooni, individuaalse elu fakt võib muutuda sotsiaalseks kogemuseks. Venemaa eestlaste eluloolisus on äärmiselt kollektiivne, seotud folklooriga, sest kogukond suhtles omavahel just sel viisil. Inimene meenutab, aga kollektiiv määrab selle, mida on vaja mäletada. Üksikisikute kogemuste asetamine üldisematesse (majanduslikesse, poliitilistesse) raamidesse aitab paremini mõista ka üldisi protsesse. Venemaa eesti kogukondades sündinud ja kasvanud eestlaste eluloolisi mälestusi (lood külade asutajatest, paiganimedest, ajaloosündmustest, perekombestikust) võib vaadelda pärimusliku ajaloona, mis põhineb rühma minevikukäsitlusel. Selle abil saame jälgida ka piirkondlikke erijooni eestlaste tavades ja kommetes ning mentaliteedimuutusi.

\section{Kommentaarid}

1 Kirjutise valmimist on toetanud Euroopa Liit Euroopa Regionaalarengu Fondi kaudu (Eesti-uuringute Tippkeskus), mis on seotud Eesti Haridus- ja Teadusministeeriumi uurimisprojektiga IUT 22-4.

${ }^{2}$ Vt küsitluskava ÜMBERASUJAD (http://www.folklore.ee/era/kysitlus/index.html). Küsitluskava koostasin 2004. aasta märtsikuus abiks mälestuste talletajatele. Aastatel 2004-2005 laekus kogumisaktsiooni käigus Eesti Rahvaluule Arhiivi (ERA) fondidesse 50 käsikirjalist või arvutil vormistatud lugu Venemaal sündinud eestlastelt (Eesti Rahvaluule Arhiivis kogu EFA, Korb I-IV).

3 Venemaal sündinud eestlastega tehtud helisalvestusi on Eesti Rahvaluule Arhiivis kokku u 165 tundi. Lühemad intervjuud kestsid 1,5 tundi, mõne inimesega tegin mitu intervjuud, kestusega kokku ligi 9 tundi. Kogud ERA helisalvestised minidiskidel (ERA, MD 232-260) ja ERA digitaalsalvestised arvuti kõvakettal (ERA, DH 26-31, 186-216). 
${ }^{4}$ Krahv Friedrich Georg Magnus von Berg (1845-1938), tuntud ka rukkikrahvina. Mitmekülgne põllumees ja sordiaretaja, kelle elutööks sai Sangaste rukki aretamine.

5 Kivine koolmekoht (vn).

${ }^{6}$ Kõrge umbrohi (vn бурьян).

7 Karjakoppel (vn).

8 Üksainuke kotike, laske läbi (vn).

9 Hästi, olgu (vn).

${ }^{10}$ Vene kodusõda (1917-1923) oli Venemaa Sotsiaaldemokraatliku Tööliste (bolševike) Partei juhtkonna juhtimisel ja toetusel endise Venemaa Keisririigi territooriumil pärast selle lagunemist tekkinud erinevate riikide "punaste" (kommunistliku ehk nõukogude suunitlusega) ja "valgete" (nõukogude ja bolševike vastaste suunitlustega) jõudude vahel toimunud relvakonflikt, mis sai alguse pärast bolševike teostatud riigipööret ja võimu haaramist 1917. aastal Petrogradis. Kõige pingelisem võitlus kestis aastatel 1918-1920.

${ }^{11}$ Midagi ei ole (vn).

12 Vanad ja uued mängud rahvaluulearhiivist, vaadatud 29. jaanuar 2018, http://www. folklore.ee/ukauka/arhiiv/items/show/3109.

${ }^{13}$ Onu, päästa (vn).

14 Rõngassai (vn).

${ }^{15}$ Kasvõi (sm).

\section{Allikad}

\section{Eesti Rahvaluule Arhiivi kogud:}

$\mathrm{H}$ - Jakob Hurda rahvaluulekogu

ERA - Eesti Rahvaluule Arhiivi rahvaluulekogu aastaist 1927-1944

RKM - Riikliku Kirjandusmuuseumi (nüüd Eesti Kirjandusmuuseumi) käsikirjaline rahvaluulekogu

\section{Kirjandus}

Aarelaid-Tart, Aili 2009. Ajakategooriast tänase Eesti kultuurimuutuste mõistmisel. Acta Historica Tallinnensia 14, lk 172-190 (doi: 10.3176/hist.2009.1.07).

Apo, Satu 1995. Naisen väki: Tutkimuksia suomalaisten kansanomaisesta kulttuurista ja ajattelusta. Helsinki: Hanki ja Jää.

ATU = Uther, Hans-Jörg 2004. The Types of International Folktales. A Classification and Bibliography. Based on the System of Antti Aarne and Stith Thompson. Part I: Animal Tales, Tales of Magic, Religious Tales, and Realistic Tales, with an Introduction. Helsinki: Suomalainen Tiedeakademia. 
Bronner, Simon J. 2017. Folklore: the basics. Routlege: London and New York.

Gusdorf, Georges 1980. Conditions and Limits of Autobiography. Olney, James (toim). Autobiography. Essays Theoretical and Critical. Princeton, New Jersey: Princeton UP, lk 28-48.

Halbwachs, Maurice 1992. On Collective Memory. Chicago: University of Chicago Press. Hiiemäe, Reet 2013. Ended ja ennustamised eesti rahvausundis. Pegasus.

Honko, Lauri 1990. Folkloreprosessi. Sananjalka 32, lk 93-121.

Humphrey, Robin \& Miller, Robert \& Zdravomyslova, Elena 2003. Introduction: biographical research and historical watersheds. Humphrey, Robin \& Miller, Robert \& Zdravomyslova, Elena (toim). Biographical Research in Eastern Europe. Altered Lives and Broken Biographies. Aldershot, Burlington: Ashgate, lk 1-24.

Jaago, Tiiu \& Jaago, Kalev 1996. See olevat olnud... Rahvaluulekeskne uurimus esivanemate lugudest. Tartu.

Jaago, Tiiu 1999. Rahvaluule mõiste kujunemine Eestis. Mäetagused 9, lk 1-17 (doi: 10.7592/MT1999.09.rtl).

Jaago, Tiiu 2001. Mis on pärimuslik ajalugu. Jaago, Tiiu (koost). Pärimuslik ajalugu. Tartu: Tartu Ülikooli Kirjastus, lk 7-15.

Jaago, Tiiu 2003a. Pere- ja suguvõsalood pärimuses. Kõresaar, Ene \& Anepaio, Terje (koost ja toim). Mälu kui kultuuritegur: etnoloogilisi perspektiive. Studia ethnologica Tartuensia 6. Tartu: Tartu Ülikooli Kirjastus, lk 33-59.

Jaago, Tiiu 2003b. "See kõik oli nii, nagu tundsin ja mõtlesin". Ühe naise elulugu pärimusliku ajaloo vaatepunktist. Jaago, Tiiu (koost). Pärimus ja tõlgendus. Artikleid folkloristika ja etnoloogia teooria, meetodite ning uurimispraktika alalt. Tartu: Tartu Ülikooli Kirjastus, lk 191-210.

Jaago, Tiiu 2006. Pärimuslik ajalugu. Argikultuuri uurimise terminoloogia e-sõnastik. Tiiu Jaago rahvaluuleloengud. Tartu Ülikool (http://argikultuur.ut.ee - 16. mai 2018).

Jürgenson, Aivar 2002. Siberi eestlaste territoriaalsus ja identiteet. Tallinna Pedagoogikaülikooli humanitaarteaduste dissertatsioonid 7. Tallinn: Tallinna Pedagoogikaülikooli Kirjastus.

Kalda, Mare 2014. Aardejutud ja nende seosed muististega. Valk, Heiki (koost, toim). Muistis, koht ja pärimus II. Paigad ja pärimus. Tartu: Tartu Ülikool, ajaloo ja arheoloogia instituut, arheoloogia osakond, lk 13-70.

Kalmre, Eda 2008. Hirm ja võõraviha sõjajärgses Tartus. Pärimuslooline uurimus kannibalistlikest kuulujuttudest. Tänapäeva folkloorist 7. Tartu: EKM Teaduskirjastus.

Kikas, Katre 2017. Rahvaluulekogujate elulood Jakob Hurda rahvaluulekogus. Keel ja Kirjandus 8-9, lk 584-599 (http://kjk.eki.ee/ee/issues/2017/8-9/958 - 16. mai 2018).

Korb, Anu 2003a. Venemaale veerenud: Siberi ja Volgamaa eestlaste päev. Mäetagused 24, lk 267-272 (http://www.folklore.ee/tagused/nr24/siber.htm - 16. mai 2018).

Korb, Anu 2003b. Siberi eestlaste surma ja matusekombestikust. Mäetagused 25, lk 103142 (doi: 10.7592/MT2003.25.anudkorb). 
Korb, Anu (koost, toim) 2010. Siberi eestlaste elud ja lood. Eesti asundused V. Tartu: Eesti Kirjandusmuuseumi Teaduskirjastus.

Kulu, Hill 1997. Eestlaste tagasiränne 1940-1989. Lääne-Siberist pärit eestlaste näitel. Publicationes Instituti geographici Universitatis Helsingiensis. Helsinki: Helsingin Yliopisto.

Kõiva, Ottilie-Olga 1964. Kihnu rahvalaulikutest. Tartu Riikliku Ülikooli Toimetised, vihik 159. Tartu: Tartu Riiklik Ülikool.

Kõiva, Mare 2011. Eesti loitsud. Tallinn: Pegasus.

Kõivupuu, Marju 2013. Igal hädal oma arst, igal tõvel ise tohter. Sissevaade Eesti rahvameditsiini. Tallinn: Varrak.

Kõivupuu, Marju 2015. Eestlase eluring. Tallinn: Varrak.

Kõresaar, Ene 2005. Elu ideoloogiad. Kollektiivne mälu ja autobiograafiline minevikutõlgendus eestlaste elulugudes. Eesti Rahva Muuseumi sari 6. Tartu: Eesti Rahva Muuseum.

Laagus, Aino 2009. Situatsioonianalüüsist folkloristikas. Mäetagused 43, lk 113-124 (doi: 10.7592/MT2009.43.laagus).

Latvala, Pauliina 2005. Katse menneisyyteen. Folkloristinen tutkimus suvun muistitiedosta. Helsinki: Suomalaisten Kirjallisuuden Seura.

Laugaste, Eduard \& Liiv, Ellen \& Normann, Erna (koost) 1963. Muistendid Suurest Tõllust ja teistest. Monumenta Estoniae Antiquae II. Eesti muistendid. Hiiu- ja vägilasmuistendid II. Tallinn: Eesti Riiklik Kirjastus.

Lotman, Juri 1990. Õigus biograafiale. Teksti ja autori isiksuse tüpoloogilisest suhestatusest. Kultuurisemiootika. Tekst - Kirjandus - Kultuur. Tallinn: Olion, lk 365-385.

Lyons, Maryn 2013. A New History from Below? The Writing Culture of European Peasants, c. 1850 - c. 1920. Kuismin, Anna \& Driscoll, M. J. (toim). White Field, Black Seeds: Nordic Literacy Practices in the Long Ninetheenth Century. Studia Fennica. Litteraria 7. Helsinki: SKS, lk 14-29 (doi: 10.21435/sflit.7).

Mikkola, Kati 2009. Tulevaisuutta vastaan. Uutuuksien vastustus, kansantiedon keruu ja kansakunnan rakentaminen. Suomalaisen Kirjallisuuden Seuran Toimituksia 1251. Helsinki: Suomalaisen Kirjallisuuden Seura.

Must, Aadu 2000. Eestlaste perekonnaloo allikad. Tartu: Kleio.

Noormets, Tiit 2015. "Kotipoisid” sõjajärgses Eestis. Tuna 4, lk 74-80 (http://www.ra.ee/ ajakiri/kotipoisid-sojajargses-eestis/ - 17. mai 2018).

Pentikäinen, Juha 1971. Marina Takalon uskonto. Helsinki: Suomalaisen Kirjallisuuden Seura.

Peltonen, Ulla-Maija 2003. Suuline ajalugu soome folklooriuurimises. Jaago, Tiiu (koost). Pärimus ja tõlgendus. Artikleid folkloristika ja etnoloogia teooria, meetodite ning uurimispraktika alalt. Tartu: Tartu Ülikooli Kirjastus, lk 177-190.

Pöysä, Jyrki 2009. Kogumisvõistlused pärimusliku ajaloo uurimises. Mäetagused 43, lk 39-54 (doi: 10.7592/MT2009.43.poysa). 
Pöysä, Jyrki \& Timonen, Senni 2004. Kuinka ahkerat muurahaiset saivat kasvot? Henkilökohtaisen tiedon paikka arkiston keruuohjeissa. Kurki, Tuulikki (toim). Kansanrunousarkisto, lukijat ja tulkinnat. Suomalaisen Kirjallisuuden Seuran Toimituksia 1002. Helsinki: Suomalaisen Kirjallisuuden Seura, lk 218-254.

Remmel, Mari-Ann (koost) 2008. Mõisalegendid. Harjumaa. Tallinn: Tänapäev.

Roos, Arand 2000. Pagulaste missioon. Jürgenson, Aivar (toim). Eestlane ja tema maa. Konverentsi "Kodumaa ja kodupaik: eestlaste territoriaalne identiteet" (16.-17. november 1999) materjale. Tallinn: Ajaloo Instituut, lk 89-97.

Rosenberg, Tiit 2010. Murrang maaomandisuhetes. Vahtre, Sulev \& Karjahärm, Toomas \& Rosenberg, Tiit (toim). Eesti ajalugu V. Pärisorjuse kaotamisest Vabadussõjani. Tartu: Ilmamaa, lk 104-137.

Tamm, Kadri 2002. Oskar Kallase ja Eesti Üliõpilaste Seltsi stipendiaatide reisikirjeldused. Hiiemäe, Mall (koost). Kogumisest uurimiseni. Artikleid Eesti Rahvaluule Arhiivi 75. aastapäevaks. Eesti Rahvaluule Arhiivi Toimetused 20. Tartu: Eesti Kirjandusmuuseum, lk 82-98.

Tammaru, Tiit \& Kumer-Haukanõmm, Kaja \& Anniste, Kristi 2010. Eesti diasporaa kujunemise kolm lainet. Praakli, Kristiina \& Viikberg, Jüri (koost). Eestlased ja eesti keel välismaal. Tallinn: Eesti Keele Sihtasutus, lk 35-57.

Tedre, Ülo 1973. Eesti pulmad. Lühiülevaade muistsetest kosja- ja pulmakommetest. Tallinn: Eesti Raamat.

Torp-Kõivupuu, Marju 2003. Surmakultuuri muutumine ajas: Ajaloolise Võrumaa matusekombestiku näitel. Monograafia. TPÜ Toimetised. Humaniora A 22. Tallinn: Tallinna Pedagoogikaülikooli Kirjastus.

Tuisk, Astrid 2001. Siberi eestlaste kohapärimus tänapäeval. Kohastumise peegeldusi. Jaago, Tiiu (koost). Pärimuslik ajalugu. Tartu: Tartu Ülikooli Kirjastus, lk 74-90.

Tuisk, Astrid 2011. Olli orja sääl koskil... Orja- ja vabadusetemaatika Siberi eestlaste väljarändamisjuttudes. Acta Historica Tallinnensia 17, lk 55-71 (doi: 10.3176/ hist.2011.2.04).

Valk, Ülo 2005. Mis on rahvaluule? Metsvahi, Merili \& Valk, Ülo (koost). Regivärsist netinaljadeni. Sissejuhatus rahvaluulesse. Tallinn: Koolibri, lk 9-12.

Valk, Ülo 2008. Saksad ja varavedajad: eesti muistendite sotsiaalset orientatsioonist. Västrik, Ergo-Hart (toim). Kes kõlbab, seda kõneldakse. Pühendusteos Mall Hiiemäele. Eesti Rahvaluule Arhiivi toimetised 25. Tartu: Eesti Kirjandusmuuseumi Teaduskirjastus.

Viikberg, Jüri 1988. Vanematest eesti asundustest Siberis. Keel ja Kirjandus 5, lk 284-288.

Winter, Jay 1997. Sites of Memory, Sites of Mourning. The Great War in European cultural history. Cambridge: Cambridge Univesity Press.

Wood, Alan 1991. Russian's Wild East: Exile, Vagrancy and Crime in NinetheenthCentury Siberia. Wood, Alan (toim). The History of Siberia. From Russian Conquest to Revolution. London \& New York: Routlege, lk 117-137.

Õnapuu, Piret 2003. Eesti pulm. Tallinn: Tänapäev. 


\title{
Summary
}

\section{Folklore and aspects of life history in the memories of Estonians living in Russia}

\author{
Anu Korb \\ Senior researcher, Estonian Folklore Archives, Estonian Literary Museum \\ anu.korb@folklore.ee
}

Keywords: life story, folklore, Estonians living in Russia

The article analyses the extent to which Estonians born and grown up in Estonian settlements in Russia have used folklore in transmitting their personal life history. The sources used in the article are memories collected in the first decades of the 21 st century from the Estonians who repatriated from Russia to Estonia in the Soviet period. The memories were collected as responses to an appeal to collect village and family history.

I came to collecting life histories and personal memories through folkloric research after having collected folklore (songs, tales, rituals and traditions, etc.) in Estonian settlements in Siberia and elsewhere in Russia for more than ten years. In the recollections of Estonians born and grown up in Russia I focused on analysing the origin stories of their ancestors and names, narratives about settling in the new homeland, the impact of dramatic historical events in the lives of their families and communities, and major life cycle events.

The time of the narrated event, the time of narrating, and the temporal space between the two interplays are creating memories of life history, as cultural memory mediates the transference of the past experience to the present day.

In collective life, folkloric environment is closely embedded in the life history environment. The collected memories contain authentic folktales, popular interpretations of history, spells, descriptions of rituals, belief reports, etc. The knowledge, experience and traditions that are passed on from one generation to another, but also stories heard, have a significant influence on an individual and are reflected also in personal history. Narratives shape the local tradition, and a fact of personal life can turn into social experience. The life history of Estonians in Russia is highly collective, bound by folklore, because this is how the community communicated. Approaching personal experiences of individuals from a more general (economic or political) perspective helps to better understand also the general processes. The life history memories of Estonians born and raised in Estonian settlements in Russia could be viewed as oral narrative history based on the group's interpretation of the past. This allows us to observe also the regional differences in the rituals and customs of Estonians as well as changes in their mentality. 